\title{
Contributions to the Wood Anatomy of the Rubioideae (Rubiaceae)
}

\author{
Steven Jansen" ${ }^{1 *}$ Frederic Lens', Salvator Ntore', Frederic Piesschaert', \\ Elmar Robbrecht ${ }^{2}$ and Erik Smets' \\ 1 Laboratory of Plant Systematics, Institute of Botany and Microbiology, K.U.Leuven, Kasteelpark Arenberg 31, \\ B-3001 Leuven, Belgium \\ 2 National Botanic Garden of Belgium, Domein van Bouchout, B-1860 Meise, Belgium
}

The secondary xylem of Craterispermeae, Coussareeae, Morindeae s.str., Prismatomerideae, Pauridiantheae, Urophylleae, and Triainolepideae (Rubiaceae, Rubioideae) is described and illustrated in detail. Genera that were previously placed in the Morindeae or Psychotrieae such as Damnacanthus, Lasianthus, Saldinia, and Trichostachys are also included. Wood anatomical characters are compared with recent phylogenetic insights into the study group on the basis of molecular data. The observations demonstrate that the delimitation and separation of several taxa from the former Coussareeae/Morindeae/Prismatomerideae/ Psychotrieae aggregate is supported by wood anatomical data. The Coussareeae can be distinguished from the other Rubioideae by their scanty parenchyma, septate libriform fibres, and the combination of uniseriate and very high multiseriate rays with sheath cells. Axial parenchyma bands and fibre-tracheids characterise Gynochtodes and some species of Morinda (Morindeae s.str.), but the latter genus is variable with respect to several features (e.g. vessel groupings and axial parenchyma distribution). Wood data support separation of Rennellia and Prismatomeris from Morindeae s.str.; vessels in both genera are exclusively solitary and axial parenchyma is always diffuse to diffusein-aggregates. Damnacanthus differs from the Morindeae alliance by the occurrence of septate fibres, absence of axial parenchyma, and the occasional presence of fibre wall thickenings. There are interesting similarities between members of the Lasianthus clade and the Pauridiantheae/ Urophyleae group such as the sporadic occurrence of spiral thickenings in axial parenchyma cells.

Key words: Rubiaceae - Rubioideae - Systematic wood anatomy

The latest subdivision of the Rubiaceae that was established by Robbrecht $(1988,1993)$ includes four subfamilies: Cinchonoideae, Ixoroideae, Antirheoideae, and Rubioideae. Several features such as the presence of raphides, valvate

\footnotetext{
* Corresponding author: steven.jansen@ bio.kuleuven.ac.be
}

aestivation, exotesta cells without perforated thickenings, frequent accumulation of aluminium in woody taxa, and often articulate hairs characterise the subfamily Rubioideae. Earlier relationships among the different tribes of this subfamily are mainly based on the number of ovules, fruit type, and habit. Several authors have emphasized a close association of the tribes Psychotrieae, Morindeae, and Coussareeae, which show fleshy fruits derived from ovaries with one solitary erect ovule in the locules (e.g. Verdcourt 1958, Petit 1963, 1964, Darwin 1979). Robbrecht (1988), who further elaborated Bremekamp's (1966) two series of Rubioideae on the basis of ovule numbers, suggested that the uniovulate Rubioideae (i.e. Psychotrieae and its two satellite tribes Triainolepideae and Lathraeocarpeae, Morindeae, Coussareeae, Paederieae, Anthospermeae, Theligoneae, Spermacoceae, and Rubieae) form a natural entity. The tribes Psychotrieae, Triainolepideae, Morindeae, and Coussareeae are mainly woody, but large herbaceous groups have evolved in the remaining tribes (Spermacoceae, Rubieae, Anthospermeae, Paederieae) which show an herbaceousness index equal to or higher than 50 (cf. Young et al. 1996).

Furthermore, the delimitation of the Morindeae has been subject to change. The genus Damnacanthus was excluded from the Morindeae s.l., with which it nearly always had been associated. This spiny shrub was found to be closely related to the herbaceous genus Mitchella and the two genera were included in a separate and informal Mitchella group on the basis of their campylotropous ovules (Robbrecht et al. 1991). Igersheim and Robbrecht (1993) restricted the tribe Morindeae to genera having bicarpellate ovaries with biovulate locules (i.e. Appunia, Caelospermum, Gynochtodes, Morinda, and Pogonolobus), while genera with truly uniovulate locules were placed in the Prismatomerideae.

Recent conclusions from cladistic analyses of sequence data contradict these earlier arrangements since the two groups of uniovulate and multiovulate Rubioideae do not form monophyletic groups (e.g. Bremer et al. 1995, Bremer 1996, Bremer and Thulin 1998, Andersson and Rova 1999, Bremer and Manen 2000, Piesschaert et al. 2000a). This has led to renewed insights in the phylogenetic relationships 
within Rubioideae (and Rubiaceae in general). For instance monophyly of the Coussareeae is supported by DNA sequences but the tribe is found to take a more basal position than the Psychotrieae-Morindeae alliance to which the Coussareeae have been connected in the past. A remarkable relationship between the tribes Coussareeae and Coccocypseleae was suggested. Morphological evidence for an extended tribe Coccocypseleae, including the shrubby genera Declieuxia and Hindsia, was recently presented by Piesschaert et al. (2000b).

The rbcL-analysis of Bremer (1996) and the rps16-intron analysis of Andersson and Rova (1999) have confirmed the close relationship between Morindeae and Psychotrieae, but macromolecular data contradicted the separation of the Mitchella group. This group was found to be the sister group of Morinda together with Gaertnera (Bremer 1996) or nested within the Morindeae (Andersson and Rova 1999, Bremer and Manen 2000). While Gaertnera appears as the sister group of Morinda in the analysis of Bremer (1996), the Gaertnereae occurred at the base of the Morindeae and Psychotrieae in the study of Andersson and Rova (1999). The genus Schradera also occupies a position close to Psychotrieae, Gaertnereae, and Morindeae (Bremer and Thulin 1998, Andersson and Rova 1999, Bremer and Manen 2000). Futhermore, $r b c L$ and $r p s 16$ intron sequences demonstrated that the genera Lasianthus, Saldinia, Ronabea and Trichostachys form a well supported "Lasianthus-clade" within the basal Rubioideae; macromolecular data suggest exclusion of these genera from the Psychotrieae or Morindeae, thus eradicating the old problem of the mutual delimitation of these two tribes. Recently, Lasianthus and Trichostachys are placed in a new tribe Lasiantheae (Bremer and Manen 2000).

While the Rubioideae, Cinchonoideae, and Ixoroideae are supported by various cladistic analyses based on molecular and/or morphological data covering the whole family, a wide circumscription of the subfamily Antirheoideae is now generally abandoned (e.g. Bremer et al. 1995, Bremer 1996, Manen and Natali 1996, Bremer and Thulin 1998, Andersson and Rova 1999, Andreasen and Bremer 2000). Accordingly, the Knoxieae and Craterispermeae are now removed from the Antirheoideae to the Rubioideae. The Knoxieae are mainly herbaceous and appear to be related to the Hedyotideae and Spermacoceae, which Bremer (1996) suggested to merge in an extended tribe Spermacoceae s.l. Although Manen and Natali (1996) suggested that Triainolepis does not belong to the Rubioideae because it lacks the typical deletion in the atpB-rbcL-spacer, the presence of raphides indicates that the genus could belong to this subfamily. Verdcourt (1958) noticed similarities in the fruit of Triainolepis and the Knoxieae. Interestingly, macromolecular data confirmed a relationship between these taxa (Piesschaert et al. 2000a). The taxonomic position of the woody and monogeneric Craterispermeae has been problematic, but macromolecular data as well as the presence of raphides and aluminium accumulation clearly supports Verdcourt's (1958) placement in the Rubioideae (Bremer and Manen 2000, Jansen et al. 2000a, b).
In two previous studies we discussed the wood anatomy of Gaertnereae and Psychotrieae (Jansen et al. 1996, 1997). The present paper aims to describe the secondary xylem of the remaining 'uniovulate' Rubioideae in order to compare the wood anatomical variation with the new phylogenetic and taxonomic insights based on macromolecular data.

\section{Materials and Methods}

Wood samples came from the herbarium of Leiden $(L)$, the wood collection of Tervuren (Tw), Utrecht (Uw), and from the National Botanic Garden of Belgium (mostly from the herbarium BR; only few samples from living collections). A list of the species studied is given below. The diameter (in $\mathrm{mm}$ ) of each wood sample is included for branch wood; the diameter of mature wood samples is unknown and not reported. Wood samples of Gentingia and Motleya (Prismatomerideae), as well as Appunia, Caelospermum, Pogonolobus (Morindeae s.str.), and Schizocolea (sole African genus of the Coussareeae) were not available. Although we were able to include a light microscopical photograph of a transverse section of Triainolepis emirensis (Fig. 46), this species could not be investigated in detail due to lack of material. Accordingly, the wood anatomical description of Triainolepis is only based on the African species Triainolepis africana. Table 1 summarises the genera and the number of wood samples studied.

Table 1. Taxa examined in the present study

\begin{tabular}{|c|c|c|c|}
\hline Tribe & Genus & $\begin{array}{c}\text { Total } \\
\text { number of } \\
\text { species }\end{array}$ & $\begin{array}{l}\text { Species/ } \\
\text { specimens } \\
\text { studied }\end{array}$ \\
\hline \multirow[t]{2}{*}{ Coccocypseleae } & Declieuxia & 27 & $1 / 1$ \\
\hline & Hindsia & 8 & $1 / 1$ \\
\hline \multirow[t]{2}{*}{ Coussareeae } & Coussarea & ca.100 & $11 / 11$ \\
\hline & Faramea & 125 & $11 / 11$ \\
\hline Craterispermeae & Craterispermum & 16 & $3 / 4$ \\
\hline Mitchella group & Damnacanthus & 6 & $1 / 1$ \\
\hline \multirow[t]{2}{*}{ Morindeae } & Gynochtodes & 14 & $2 / 2$ \\
\hline & Morinda & 50 & $9 / 10$ \\
\hline \multirow[t]{4}{*}{ Pauridiantheae } & Commitheca & 1 & $1 / 1$ \\
\hline & Pauridiantha & 25 & $3 / 3$ \\
\hline & Poecilocalyx & 2 & $2 / 2$ \\
\hline & Stelecantha & 1 & $1 / 1$ \\
\hline \multirow[t]{2}{*}{ Prismatomerideae } & Prismatomeris & 25 & $4 / 5$ \\
\hline & Rennellia & 10 & $2 / 2$ \\
\hline Triainolepideae & Triainolepis & 2 & $1 / 2$ \\
\hline \multirow[t]{5}{*}{ Urophylleae } & Leucolophus & 3 & $1 / 1$ \\
\hline & Maschalocorymbus & 4 & $2 / 2$ \\
\hline & Pleiocarpidia & 27 & $2 / 2$ \\
\hline & Praravinia & 50 & $2 / 2$ \\
\hline & Urophyllum & 150 & $4 / 4$ \\
\hline \multirow[t]{3}{*}{ Lasianthus group } & Lasianthus & 150 & $6 / 9$ \\
\hline & Saldinia & 2 & $1 / 2$ \\
\hline & Trichostachys & 10 & $1 / 2$ \\
\hline
\end{tabular}


Wood blocks were sectioned and macerated according to standard methods (Jansen et al. 1998). The specimens were studied with a light microscope (LM; Leica DMLB) and a scanning electron microscope (SEM; Jeol JSM-6400). Vessel element length and fibre length were measured from macerations, 30 elements per sample. The vessel grouping index is used as defined by Carlquist (1988). According to this method, the total number of vessels counted as individuals is divided by the total number of vessel groups. For quantitative features (e.g. the tangential diameter of vessel lumina), the average is given for all specimens studied and the numbers between brackets refer to the total range for all samples. Terminology follows the IAWA list (IAWA Committee 1989).

\section{List of materials studied}

Commitheca liebrechtsiana (De Wild. \& T. Durand) Bremek., Democratic Republic of Congo, Yangambi, J. Louis 7992 (BR), $6 \mathrm{~mm}$-Coussarea aff. grandis Müll.Arg., Venezuela, $\mathrm{s}$. loc., collector unknown (Tw 36177)-C. contracta (Walp.) Benth. \& Hook. ex Müll.Arg., Brazil, Parama, Lindeman \& De Haas 2956 (Tw 35300)-C. cuatrecasasii Standl. ex Steyerm., Colombia, s.loc., J. Cuatrecasas 16587 (Tw 39561)-C. hirticalyx Standl., Peru, Loreto, La Victoria, L. Williams 2528 (Tw 46671)—C. leptoloba (Spreng. ex Benth. \& Hook.f.) Müll.Arg., Brazil, Amazonas, SãoPaulo de Olivenga, B.A. Krukoff 8203 (Tw 38662)-C. machadoana Standl., Brazil, Machado River, B.A. Krukoff 1361 (Tw 34638)-C. megalocarpa Standl., Peru, Loreto, Rio Mazan, L. Williams 8171 (Tw 38704)-C. ovalis Standl., Peru, Loreto, Rio Ituya, L. Williams 3355 (Tw 46672) -C. surinamensis Bremek., Surinam, s.loc., Stahel 280 (Tw 25832)-C. tenuiflora Standl., Peru, Loreto, L. Williams 8152 (Tw 38661)-C. vallis Standl. ex Steyerm., Colombia, s.loc., J. Cuatrecasas 17593 (Tw 39656)-Craterispermum cerinanthum Hiern, Democratic Republic of Congo, Kouilou, H. de Foresta 55 (Tw 48567), $15 \mathrm{~mm}$; Democratic Republic of Congo, A. Madoux 267 (Tw 41594)-C. laurinum (Poir.) Benth., Madagascar, Tamatave, Thouvenot 26 (Tw 30111) -C. schweinfurthii Hiern, Democratic Republic of Congo, Bokoli, R. Dechamps 8017 (Tw 40317), $18 \mathrm{mm-Damnacanth-}$ us indicus P. Gaertn., Japan, Nagasaki, R. Oldham s.n. (BR-S. P. 802815), $5 \mathrm{~mm}$-Declieuxia fruticosa (Willd. ex Roem. \& Schult.) Kuntze, Brazil, $25 \mathrm{~km} \mathrm{~N}$ of Alto Paraiso, W.R. Anderson 6687 (BR), $5 \mathrm{~mm}$-Faramea amplifolia Standl., Peru, Pebas, L. Williams 1946 (Tw 46678)-F. anisocalyx Poepp. \& Endl., Peru, lquitos, L. Williams 1330 (Tw 38657), 38 mm-F. elegans Standl. ex Steyerm., Colombia, s.loc., J. Cuatrecasas 15721 (Tw 39477)-F. glandulosa Poepp. \& Endl., Peru, San Martin, L. Williams 6093 (Tw 38696)-F. neblinae Steyerm., Venezuela, Amazonas, B. Maguire et al. 27926 (Tw 36412) -F. occidentalis (L.) A. Rich. var. meridionalis Steyerm., British Guyana, Moku-moku Creek, A.C. Smith 3478 (Tw 27351)-F. parvibracteata Steyerm., Venezuela, Amazonas, $B$. Maguire et al. 28424 (Tw 36315)-F. quadricostata Bremek., Surinam, Nickerie, B. Maguire et al. 54664, (Tw 37669)-F. rectinervia Standl., Peru, La Victoria, L. Williams 2962 (Tw 38665)-F. stenopetala Mart., Venezuela, Amazonas, B. Maguire et al. 42717 (Tw 36911)—F. warmingiana Müll.Arg., Brazil, Para, B.
Maguire et al. 56992 (Tw 38134)-Gynochtodes sp., Irian Jaya, s.loc., $M$. Jacobs 9670 (L), $17 \mathrm{~mm}$ - G. coriacea Blume, Sumatra, s.loc., M. Jacobs 8118 (L)-Hindsia longiflora (Cham.) Benth., Brazil, Minas Geraes, $P$. Claussen 235 A (BR), $6 \mathrm{~mm}$ -Lasianthus sp., Borneo, Bukit Raya, H.P. Nooteboom 4026, $10 \mathrm{~mm}, 4034$ \& 4189 (L), $13 \mathrm{~mm}-L$. acuminatus Wight, India, Cardamom Hills, C.E. Ridsdale 167 (L)-L. batangensis $\mathrm{K}$. Schum., Democratic Republic of Congo, Ngula, affluent Aruwini, J. Louis 15492 (BR); Democratic Republic of Congo, Yangambi, J. Louis 11587 (BR), 9 mm; Democratic Republic of Congo, J. Louis 3042 (Tw 33582)-L. cinereus Gamble, India, Walaiyar Estate, Papanasam Tamil Nadu, C.E. Ridsdale 336 (L), $10 \mathrm{~mm}$ - L. mayumbensis Good, Democratic Republic of Congo, Kouilou, Les Sara, R. Dechamps 13165 (Tw 49225), $10 \mathrm{~mm}-$ L. scabridus King \& Gamble, Malaysia, Hutan Simpan Bukit Kesing, Terengganu, L.E. eo T. \& P. 1133 (KL 3633), $12 \mathrm{~mm}$-Leucolophus sp., Indonesia, North Sumatra, W. de Wilde \& B. de Wilde-Duyfjes 13721 (L)-Maschalocorymbus sp., Borneo, Bukit Raya, H.P. Nooteboom 4264 (L) -M. corymbus (Blume) Bremek., Borneo, Sarawak, Jacobs 5290 (L)-Morinda angustifolia Roxb., Thailand, Chiang Mai, Mae Chan, J.F. Maxwell et al. 94 (L) - M. citrifolia L., National Botanic Garden of Belgium, cultivation number 195924856010, $17 \mathrm{~mm}$; India, Andhra Pradesh, Birla Institute of Scientific Research Amlai (M.P.) nr. 0131 (Tw 46621)-M. debilis (Sandwith) Steyerm., Guyana, s.loc., Stoffers et al. 069 (Uw 27677), $14 \mathrm{~mm}-M$. geminata DC., Democratic Republic of Congo, Kasai, R. Dechamps 7686 (Tw 51575)-M. lucida Benth., s.loc., G. Gilbert 165 (BR), $10 \mathrm{~mm}-M$. morindoides (Baker) Milne-Redh., Democratic Republic of Congo, Lieki (Lomani), J. Louis 3662 (BR), $7 \mathrm{~mm}$; Cameroon, Bretous, Breteler 747 (Uw 9264), $18 \mathrm{~mm}-M$. myrtifolia A. Gray, Society Islands, Grant 5143 (BISHw 2660)-M. reticulata Benth., India, Ponmudi, Kerala, C.E. Ridsdale 469 (L), $20 \mathrm{~mm}-$ M. umbellata L., s. loc., Colonial Museum of Haarlem 1507-32 (L), 14 mm -Pauridiantha viridiflora (Schweinf. ex Hiern) Hepper, Angola, d'Uige vers Negage, R. Dechamps 1545 (Tw 28636)-P. pyramidata (K. Krause) Bremek., Democratic Republic of Congo, R. Dechamps 8082 (Tw 40380), $20 \mathrm{~mm}-P$. rubens (Benth.) Bremek., Democratic Republic of Congo, J. Louis 1254 (Tw 33126), 21 mm-Pleiocarpidia sandahanica Bremek., Borneo, Sarawak, Jacobs 5291 (L)-P. pilosa (Ridl.) Bremek., Borneo, Bukit Raya, H.P. Nooteboom 4473 (L)-Poecilocalyx schumannii Bremek., Cameroon, Kribi-Lolodorf km. 16, Bos 3665 (BR)-P. stipulosa (Hutch. \& Dalziel) N. Hallé, Liberia, Bassa, Cooper 205 (Tw 26696), 22 mm-Praravinia sp., Indonesia, Sulawesi, Utara, Edwards Camp, Dumoga Nat. Park, De Vogel \& Vermeulen 6775 (L)-P. suberosa (Merr.) Bremek., Borneo, North Kalimantan, Forest Dept. 10,640 (L), 7 $\mathrm{mm}$-Prismatomeris sp., Philippine Islands, Palawan, A.C. Podzorski SMHI 2095 (L)_P. beccariana (Baill. ex K. Schum.) J.T. Johanss., Borneo, Bukit Raya, H.P. Nooteboom 4336 (L), $8 \mathrm{~mm}$; Borneo, Sarawak, Jacobs 5423 (L)-P. brachypus Ridl., Philippine Islands, Surigao, C.A. Wenzel 2878 (BR), 4 $\mathrm{mm}-P$. tetrandra (Roxb.) K. Schum. subsp. malayana (Ridley) J.T. Johansson, s. loc., W. Griffith s.n. (BR-S.P. 809987), 5 mm-Rennellia sp., Borneo, s.loc., Fuchs 21358 (L)-R. elliptica Korth., Borneo, Bukit Raya, H.P. Nooteboom 4136 (L) 
-Saldinia sp., Madagascar, E. of Fianarantsoa, Parc National de Ranomafana, R. Rakoto 301 (BR), $4 \mathrm{~mm}$; Madagascar, Toamasina, E. coast, litoral forest, S. of Amirca-Lemaitso, Lewis \& S. Razafimandimbison 723 (BR), $5 \mathrm{~mm}$-Stelechantha makakana N. Hallé, Cameroon, N'KolandamN'Koemvome, J.J.F.E. de Wilde 8009 (BR)-Triainolepis africana Hook.f. subsp. hildebrandtii (Vatke) Verdc., s.loc., J.B. Gillet \& S.P. Kibuwa 19850 (BR), 4 mm; Kenya, Kwale District, Diani, J.P.M. Brenan et al. 14512 (BR), 4 mm-T. emirensis (Baker) Bremek., Madagascar, Antananarivo, L.J. Dorr 3273 (Tw 46748)-Trichostachys microcarpa K. Schum., s. loc., R. Devred 7678 (BR), $8 \mathrm{~mm}$, and R. Devred 2883 (BR), 5 $\mathrm{mm}$-Urophyllum cf. macrophyllum, Borneo, W. Kalimantan, Danau Sentarum Wildlife Reserve, Belitung River, W. Giessen 89 (L), $10 \mathrm{~mm}-U$. corymbosum Korth., Indonesia, Malaya, Jalan Bukit Tersek, KL 3157, T. \& P. 557 (L)-U. trifurcum H. Pearson ex King, Indonesia, Malaya, Pahang, collectors: T. \& P. 781 (L), $9 \mathrm{~mm}-U$. zeylanicum Thwaites, Sri Lanka, Kandy distr., Knuckles, from Rangala to Looloowatte, Nooteboom 3056 (L), $15 \mathrm{~mm}$.

\section{Results}

Generic descriptions are given below for each tribe separately. Detailed wood anatomical data of the specimens studied are listed in Table 2.

Coccocypseleae Bremekamp (sensu Piesschaert et al. 2000b) The third genus of this tribe, Coccocypselum, is entirely herbaceous.

Declieuxia Kunth. (1 species/1 specimen examined)-Fig. 1.

Growth rings are indistinct.-Vessels are diffuse. Vessel grouping index is 1.23. Mean length of vessel elements is $436(370-510) \mu \mathrm{m}$. Tangential vessel diameter is $21(17-30)$ $\mu \mathrm{m}$. The number of vessels per $\mathrm{mm}^{2}$ is more than 100 . Narrow vessel elements that sometimes show a single, very small perforation are frequently found. Vessel elements perforations are simple. Intervessel pits and vessel-ray pits are alternate, minute, and vestured.-Fibre pits are simple or with reduced pit borders. At least some fibres are septate. Mean length of fibres is 585 (500-620) $\mu \mathrm{m}$.-Axial parenchyma is not observed.-Rays are heterogeneous, uni- to triseriate, and generally more than $1 \mathrm{~mm}$ high.--Raphides are present in $D$. fruticosa.

Hindsia Benth. ex Lindl. (1 species/1 specimen examined) -Fig. 2.

Growth rings are absent.-Vessels are diffuse. Vessel grouping index is 1.76. Mean length of vessel elements is 371 (300-450) $\mu \mathrm{m}$; mean tangential diameter is $20(17-30)$ $\mu \mathrm{m}$. Vessel frequency is high $\left(>100\right.$ vessel $\left./ \mathrm{mm}^{2}\right)$. Fibriform vessel elements are frequently present. Vessel elements perforations are simple. Intervessel pits and vesselray pits are alternate, minute, and vestured.-Fibres are septate. Fibre pits are simple or with reduced pit borders. Mean length of fibres is $598(500-700) \mu \mathrm{m}$.-Axial parenchyma is not observed.-Rays are heterogeneous and uni- or biseriate, with usually more than 4 rows of marginal ray cells, and more than $1 \mathrm{~mm}$ high. The biseriate rays are wider than the uniseriate rays. - Mineral inclusions are absent.

\section{Coussareeae Hook.f.}

Coussarea Aubl. (11 species/11 specimens examined)-Figs. $6,7,11$

Growth rings are absent or indistinct.-Vessels are diffuse. The vessel grouping index averages 1.65, varying from $1.3(C$. ovalis) to 2.16 (C. leptoloba). Mean length of vessel elements is $1,023(600-1,500) \mu \mathrm{m}$; mean tangential vessel diameter is $53(30-150) \mu \mathrm{m}$. Vessels about $116 \mu \mathrm{m}$ wide are found in C. vallis only (Fig. 6). Mean number of vessels per $\mathrm{mm}^{2}$ is $45(15-120)$. Vessel element perforations are simple. However, the number of perforations per perforation plate is frequently more than one (Fig. 11); for instance up to five perforations are observed in a perforation plate of C. machadoana. Perforated ray cells show simple perforations, but they are sometimes irregular in shape, or irregularly reticulate as e.g. in C. vallis. Intervessel pits are alternate or rarely opposite to scalariform, mostly polygonal, and vestured. Intervessel pits are minute $(<4 \mu \mathrm{m})$, small $(4-7 \mu \mathrm{m})$, or medium $(7,8 \mu \mathrm{m})$ sized. Vessel-ray pits are similar to intervessel pits with distinct pit borders, but enlarged with reduced pit borders in $C$. vallis.-Fibres are septate with simple to minutely bordered pits confined to radial fibre walls (Fig. 7). Septa are not observed in fibres of $C$. aff. grandis. Mean length of fibres is $1652(800-2,400) \mu \mathrm{m}$.-Axial parenchyma is scanty paratracheal, very rare and often seemingly absent or lacking. Axial parenchyma strands are composed of 5 to 10 cells. - The heterogeneous rays usually are of two distinct sizes: uniseriate and 4-seriate or wider (up to 10 cells in C. megalocarpa). Relatively narrow rays (2-3-seriate) occur in $C$. tenuiflora. The body ray cells are usually procumbent with mostly 2-4 rows of upright and/or square marginal cells. Sheath cells partly surround the rays in most multiseriate rays (except $C$. tenuiflora). Multiseriate rays are very high, on average $2,752 \mu \mathrm{m}$, but rays up to $10,100 \mu \mathrm{m}$ high occur in C. megalocarpa. The number of rays per $\mathrm{mm}$ is 10 (6-19).-Raphides are abundantly present in the upright/ square ray cells of most species studied. Raphides are lacking in C. aff. grandis, C. hirticalyx, and C. leptoloba.

Faramea Aubl. (11 species/11 specimens examined)-Figs. 810.

Growth rings are absent or indistinct.-Vessels are diffuse and mean vessel grouping index is 1.62, varying from 1.08 in $F$. rectinervis to 2.76 in $F$. parvibracteata. Vessel outline is oval or slightly angular. Vessel lumina are 46 (18-74) $\mu \mathrm{m}$ wide. Mean number of vessels per $\mathrm{mm}^{2}$ is 57 (24-110). Vessel element length is $849(400-1,300) \mu \mathrm{m}$. Vessel element perforations are simple and frequently vestured. As in Coussarea, however, a single perforation plate is often composed of two or three perforations close to each other. Perforated ray cells show simple (e.g. F. anisocalyx) or scalariform (e.g. F. elegans) perforations. Intervessel pits are alternate, vestured, and frequently polygonal. Size of intervessel 

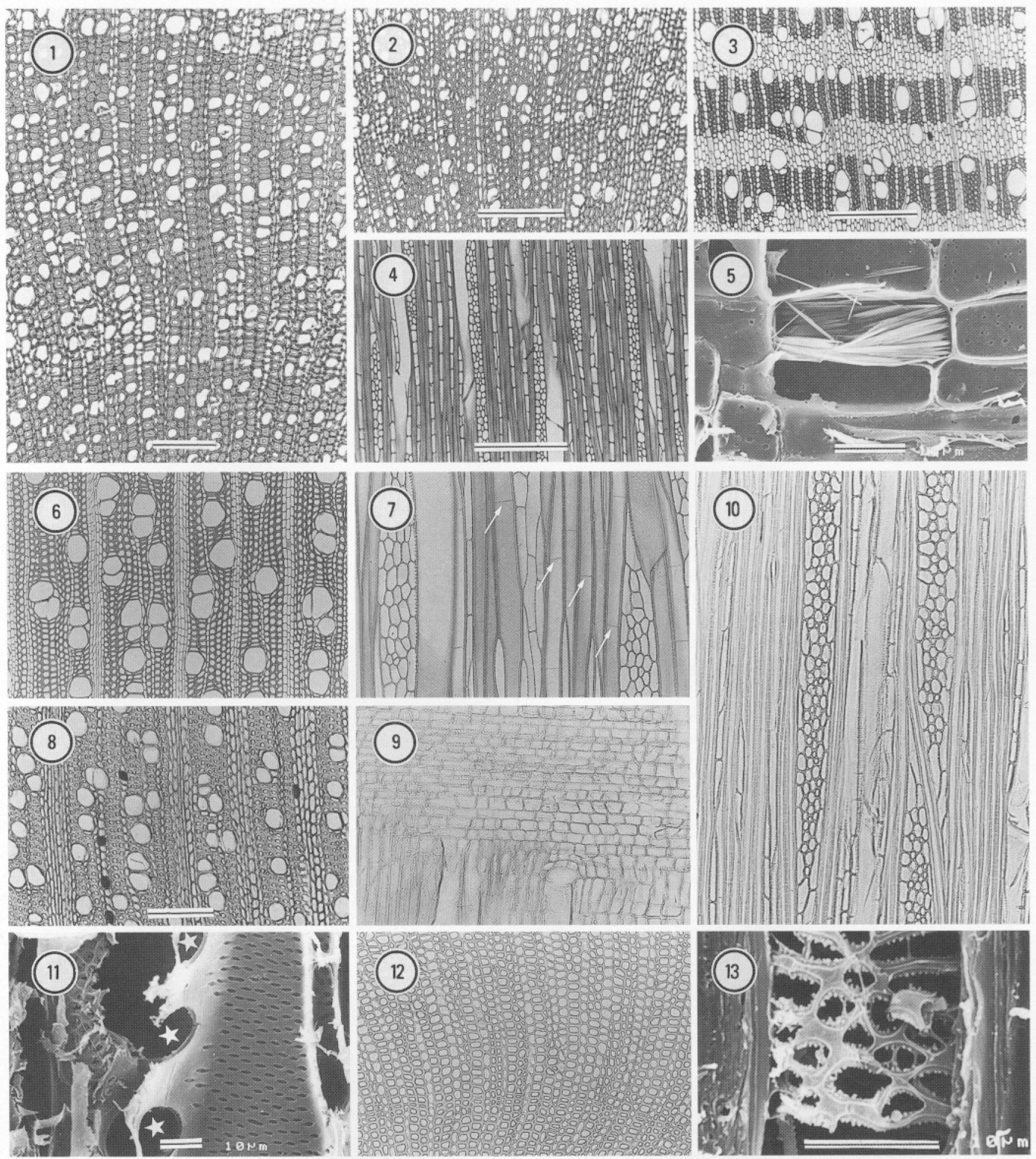

Figs. 1-13. Wood of Coccocypseleae (1-2), Craterispermeae (3-5), Coussareeae (6-11), and Damnacanthus (12-13). 1-4, 6-10, 12: Light micrographs of wood sections. 5, 11, 13: Scanning electron micrographs. 1: Declieuxia fruticosa. Transverse section (bar=100 $\mu \mathrm{m}$ ). 2: Hindsia longiflora. Transverse section $(\mathrm{bar}=200 \mu \mathrm{m})$. 3: Transverse section of Craterispermum laurinum showing wide axial parenchyma bands $(\mathrm{bar}=500 \mu \mathrm{m})$. 4 : Tangential section of Craterispermum laurinum (bar $=200 \mu \mathrm{m}$ ). 5: Raphides in ray parenchyma cell (bar $=40 \mu \mathrm{m}$ ). 6-7: Coussarea vallis. Transverse section (6; bar as in 3) and tangential section (7; bar as in 2) with septate (arrows) libriform fibres. 8: Faramea occidentalis. Transverse section with raphides visible as dark spots in the rays $(b a r=200 \mu \mathrm{m})$. 9: Radial section of Faramea warmingiana (bar as in 2). 10: Faramea glandulosa showing 3-4-seriate rays with sheath cells in tangential section (bar as in 1). 11. Faramea anisocalyx. Oblique perforation plate of vessel elements with three simple perforations (stars) $(\mathrm{bar}=10 \mu \mathrm{m})$. 12-13: Damnacanthus indicus. Transverse section (12; bar as in 1) and detail of fibre wall thickenings with vestures viewed from the outer surface, the original secondary fibre wall is removed $(13 ;$ bar $=10 \mu \mathrm{m})$. 
pits is minute, but small intervessel pits $(4-7 \mu \mathrm{m})$ occur in $F$. anisocalyx. Vessel-ray pits are similar to intervessel pits. -Fibres are septate and show simple to minutely bordered pits (pit diameter 2-3 $\mu \mathrm{m}$ ) on radial fibre walls. Fibre length is $1,420(730-2,000) \mu \mathrm{m}$.-Axial parenchyma is scanty paratracheal, with five to ten cells per parenchyma strand. -Rays are heterogeneous, and of two distinct sizes: uniseriate and 4-seriate or wider (Fig. 10). Rays up to 16 cells wide are observed in F. neblinae. Rays are not more than three cells wide in F. elegans and occasionally 4-seriate in $F$. quadricostata and $F$. parvibracteata. The multiseriate rays are relatively high, on average $1,567 \mu \mathrm{m}$, but rays up to 9,620 $\mu \mathrm{m}$ in height are found in F. quadricostata. Sheath cells generally form an incomplete sheath around the procumbent cells (Fig. 10). The rays are composed of procumbent body ray cells with usually $2-4$ rows of upright/square marginal ray cells (Fig. 9). The number of rays per $\mathrm{mm}$ is ca. $10(6-17)$. -Raphides are abundantly present in ray cells (Fig. 8), especially in upright/square ray cells of several species.

\section{Craterispermeae Verdc.}

Craterispermum Benth. (3 species/3 specimens examined) -Figs. 3-5.

Growth rings are absent--Vessels are diffuse and the mean vessel grouping index is 1.2. Vessel lumina are on average 55 (25-90) $\mu \mathrm{m}$ wide; mean number of vessels per $\mathrm{mm}^{2}$ is 36 (11-68). Mean vessel element length is $960(600-$ 1,500) $\mu \mathrm{m}$. Vessel element perforations are simple. Perforated ray cells with simple perforations are present. Intervessel pits are alternate, minute, and vestured. Vessel-ray pits show distinct borders and are similar to intervessel pits in size and shape throughout the ray cell.-Fibres are nonseptate, with distinctly bordered pits on radial and tangential walls. Diameter of the pit border is ca. 3-4 $\mu \mathrm{m}$. Mean fibre length is $1,680(1,000-2,250) \mu \mathrm{m}$.-Axial parenchyma bands are continuous, $4-5$ cells or $142(60-280) \mu \mathrm{m}$ wide (Fig. 3 ). Parenchyma strands are composed of 5-20 cells. The distance between the parenchyma bands is on average 384 (200-670) $\mu \mathrm{m}$.- Rays are heterogeneous and usually 2-3 -seriate (Fig. 4). Body ray cells are procumbent, with numerous rows of upright/square marginal cells. Rays are on average $1,017(300-3,300) \mu \mathrm{m}$ high. The number of rays per $\mathrm{mm}$ is ca. 14 (11-20).-Raphides are present in axial parenchyma cells or ray cells of all species studied (Fig. 5).

The Mitchella group

Damnacanthus C.F. Gaertn. (1 species/1 specimen examined) -Figs. 12 and 13.

Growth rings are indistinct and formed by a difference in fibre wall thickness.-Vessels are very narrow and difficult to distinguish from fibres in transverse sections (Fig. 12). Tangential diameter of vessel lumina is $24(20-27) \mu \mathrm{m}$. Vessel element length is $693(600-900) \mu \mathrm{m}$. Vessel element perforations are simple and vestured. The openings of the perforations are elliptical, sometimes irregular or mismatched. Intervessel pits and vessel-ray pits are alternate, minute, and vestured.-Fibres are septate. Fibre pits with pit chambers 2-3 $\mu \mathrm{m}$ in diameter occur on radial and tangential walls.
Fibre length is $906(700-1,000) \mu \mathrm{m}$. Occasionally, vesturing is found in association with fibre wall thickenings. The illustration shown in Fig. 13 illustrates the outer surface of the newly deposited fibre thickenings, while the original secondary fibre wall in Fig. 13 is removed by the cutting action during sample preparation. The vestures arise from the thickenings into the depressions which frequently appear just like vestured pits of vessel elements. SEM observations illustrated that the fibre thickenings containing the primary wall were sometimes found to be detached from the inner surface of the secondary wall. Small unbranched vestures also spread out on the inner surface of the thickenings forming narrow lines.-Axial parenchyma is absent. -Rays are heterogeneous, 3-4-seriate, and sometimes 56 -seriate. The body ray cells are mostly procumbent with 2-4 or more rows of upright/square ray cells. Rays average $1,145 \mu \mathrm{m}$ high, and more than 15 rays occur per $\mathrm{mm}$. -Mineral inclusions are absent.

\section{Morindeae Miq.}

Gynochtodes Blume (2 species/2 specimens examined) -Figs. 14-17.

Growth rings are absent.-Vessels are exclusively solitary, and round to oval. The tangential diameter of vessel lumina is very wide, on average $247(150-300) \mu \mathrm{m}$; narrow vessels about $40 \mu \mathrm{m}$ wide are occasionally present. Mean number of vessels per $\mathrm{mm}^{2}$ is 6 (4-10). Vessel element perforations are simple. Vessel pits are alternate, $7-9 \mu \mathrm{m}$ in diameter, and vestured. Vessel-ray pits are similar to other types of vessel pits (Fig. 17).-Fibre-tracheids are non-septate, with numerous distinctly bordered and vestured pits on radial and tangential fibre walls (Figs. 15-16). Mean fibre length is 870 (700-1,100) $\mu \mathrm{m}$.-Axial parenchyma bands are discontinuous, usually more than four cells wide, and the distance between the bands is highly variable (Fig. 14). Axial parenchyma strands are composed of seven to nine cells.-Rays are near homogeneous. They are uniseriate or biseriate in part (Fig. 15). The body ray cells are procumbent, with one row of square or upright marginal ray cells. Rays are 287 (100-630) $\mu \mathrm{m}$ high. The number of rays per $\mathrm{mm}$ varies from 11 to 14 . -Raphides are present in axial parenchyma cells.

Morinda L. (9 species/9 specimens examined)_Figs. 18-23.

Growth rings are absent or indistinct.-Vessel grouping is variable. Vessels are exclusively solitary in $M$. foresteri and mainly solitary in $M$. debilis, $M$. morindoides, and $M$. reticulata. The vessel grouping index is about 1.5 in $M$. citrifolia, and vessels are predominantly in radial multiples in $M$. citrifolia (Tw 46621), M. lucida, M. geminata, and $M$. angustifolia (vessel grouping index about 2). Vessels are in radial multiples of more than four in $M$. angustifolia and $M$. citrifolia. Length of vessel elements is $504(150-1,300) \mu \mathrm{m}$. Vessel frequency averages about 25 vessels per $\mathrm{mm}^{2}$. The mean tangential diameter of vessel lumina is very wide in $M$. morindoides Uw $9,264(240 \mu \mathrm{m})$, and wide in $M$. reticulata $(143 \mu \mathrm{m})$ and $M$. geminata $(110 \mu \mathrm{m})$. Narrow vessels of ca. $28 \mu \mathrm{m}$ occur in $M$. debilis. Other specimens studied show vessels of ca. 70 $\mu \mathrm{m}$ wide. Vessel element perforations are simple. Inter- 


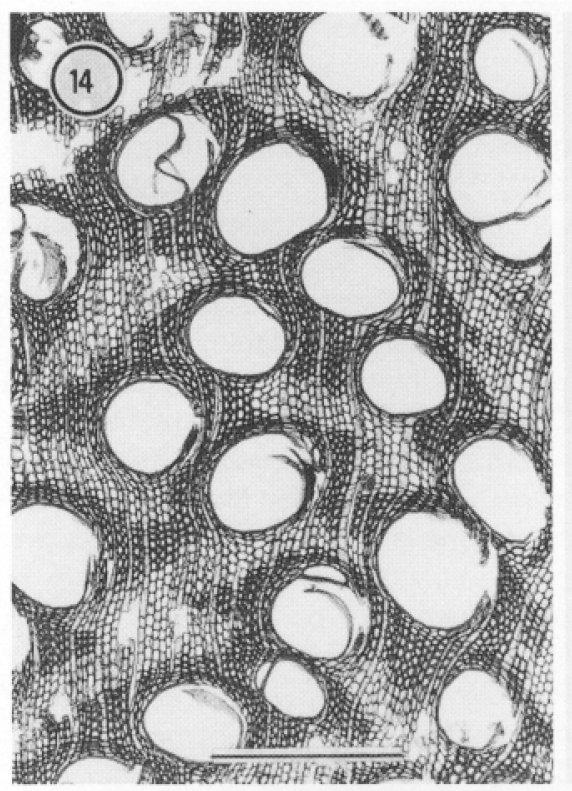

(15)
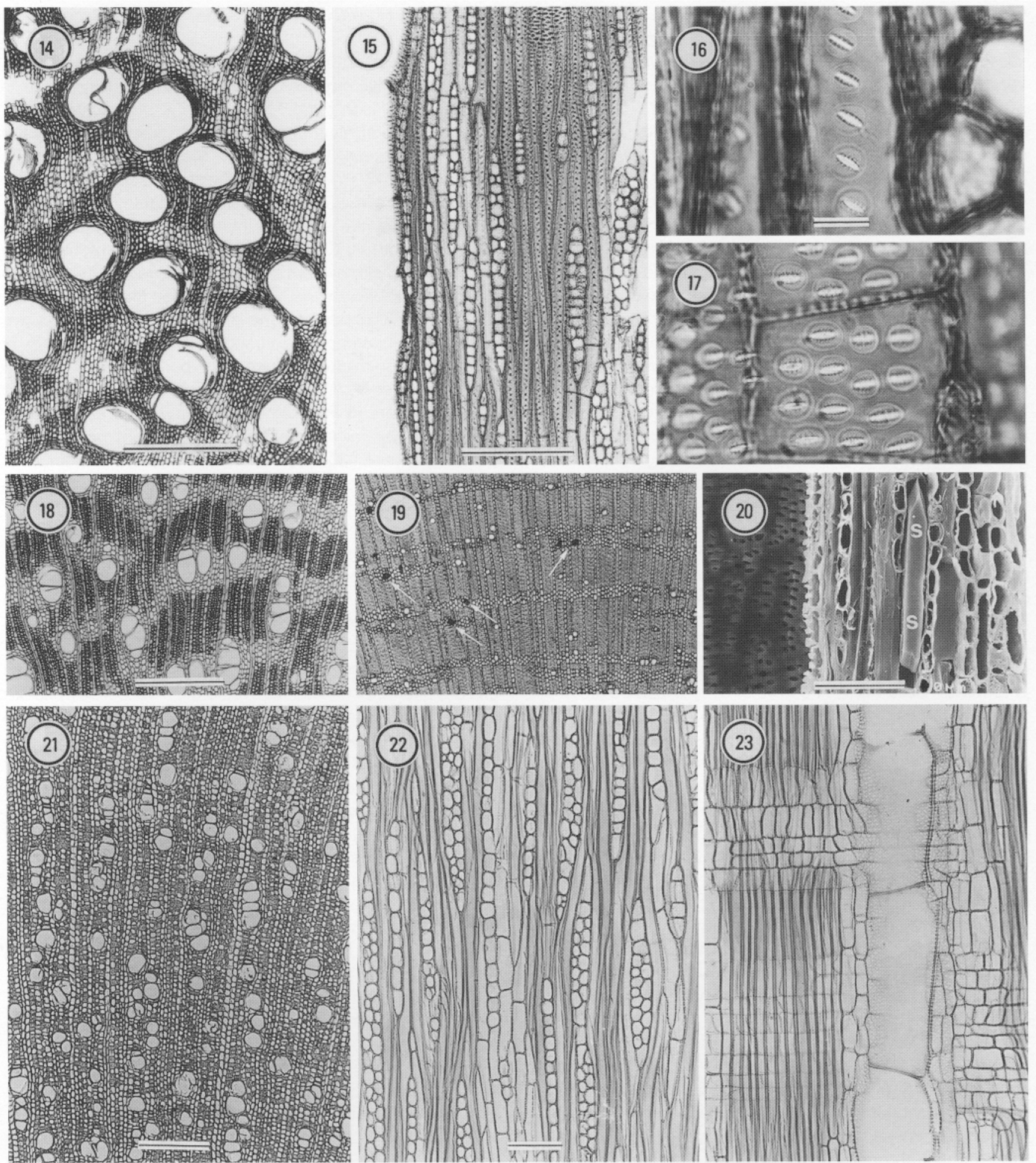

Figs. 14-23. Wood of Morindeae. 14-19, 21-23: Light micrographs. 20: Scanning electron micrograph. 14-17: Gynochtodes sp. 14: Transverse section showing wide vessels and axial parenchyma bands $(\mathrm{bar}=500 \mu \mathrm{m}) . \quad 15$ : Tangential section with 1-2-serjate rays, axial parenchyma strands and pitted fibre walls $(\mathrm{bar}=200 \mu \mathrm{m})$. 16: Detail of vestured fibre pits on tangential fibre wall $(\mathrm{bar}=10 \mu \mathrm{m})$. 17: Detail of vestured vesselray pits (bar as in 16). 18: Morinda lucida. Axial parenchyma bands in transverse section (bar $=500 \mu \mathrm{m})$. 19: Morinda debilis. Transverse section showing narrow vessels and axial parenchyma bands. Raphides are present in axial parenchyma cells indicated by arrows (bar as in 18). 20: Morinda morindoides (Breteler 747). Detail of tangential section with styloid (indicated by S) in axial parenchyma cell (bar $=60 \mu \mathrm{m}$ ). 21 : Morinda citrifolia (cultivated at BR). Transverse section showing vessels solitary and in radial multiples. Axial parenchyma distribution is diffusein-aggregates (bar=250 $\mu \mathrm{m})$. 22-23: Morinda lucida. Tangential section $(22 ;$ bar $=100 \mu \mathrm{m})$ and radial section $(23$; bar as in 22). 
vessel pits are alternate and generally more than $4 \mu \mathrm{m}$ in diameter. Vessel pits are mostly vestured, but non-vestured vessel pits occur especially in specimens with (very) wide vessels (e.g., M. morindoides and $M$. reticulata). Vessel-ray pits are enlarged with reduced pit borders in $M$. reticulata and M. morindoides, but similar to intervessel pits in all other species (Fig. 23).-Fibre-tracheids with distinctly bordered pits on radial and tangential walls are present. Fibre pits in M. geminata, however, are simple to minutely bordered. Fibre length is $1,086(500-1,950) \mu \mathrm{m}$.-Distribution of the axial parenchyma is variable but parenchyma bands are most common. These are four or five cells wide (Fig. 18), but some species show narrow bands that are two or three cells wide (Fig. 19). M. geminata and M. morindoides (Uw 9264) show parenchyma bands much more than four cells wide (from 100 to $230 \mu \mathrm{m}$ ). The distance between the bands is variable, e.g. from 50 to $210 \mu \mathrm{m}$ in $M$. debilis and from 200 to $400 \mu \mathrm{m}$ in M. lucida. Axial parenchyma is diffuse to diffusein-aggregates, with small lines 1 or 2 cells wide in $M$. angustifolia and $M$. foresteri, but only diffuse-in-aggregates in $M$. citrifolia (Fig. 21). Scanty paratracheal parenchyma is also found in $M$. morindoides. The axial parenchyma strands are composed of 3 to 12 cells.-Rays are mostly heterogeneous (Fig. 22, 23), but homogeneous rays are found in $M$. morindoides (Uw 9264) and near homogeneous rays occur in $M$. geminata and $M$. citrifolia. The rays are 1-3-seriate, but 45 -seriate rays occur in $M$. geminata and $M$. citrifolia. Rays in $M$. debilis, $M$. foresteri, and $M$. morindoides are exclusively or predominantly uniseriate. They are mainly composed of procumbent cells with some rows of upright/square marginal cells. Mean height of the rays is $700(100-2,300) \mu \mathrm{m}$. The number of the rays per $\mathrm{mm}$ is $11(7-17)$.- - Raphides are present in axial parenchyma cells of $M$. morindoides (UW 9264), M. debilis (Fig. 19), M. reticulata, and M. citrifolia. The axial parenchyma cells are distinctly enlarged in $M$. debilis. Styloids (150 to $250 \mu \mathrm{m}$ long; $15-20 \mu \mathrm{m}$ wide) occur in parenchyma cells of M. morindoides (Uw 9264; Fig. 20).

\section{Pauridiantheae Bremek. ex Darwin}

Commitheca Bremek. (1 species/1 specimen examined)

Growth rings are indistinct.-Vessels are diffuse, solitary or in short radial multiples. Vessel grouping index is 1.42 . The tangential diameter of vessel lumina averages 39 (3050) $\mu \mathrm{m}$. Mean number of vessels per $\mathrm{mm}^{2}$ is $66(52-80)$. Vessel element perforations are simple and sometimes vestured. Intervessel pits are alternate, minute, and vestured. Vessel-ray pits are similar to intervessel pits. Mean vessel element length is $841(600-1,100) \mu \mathrm{m}$.-Fibre-tracheids are non-septate, with numerous distinctly bordered pits on radial and tangential fibre walls. Mean fibre length is $1,273(800-1,600) \mu \mathrm{m}$.-Axial parenchyma is diffuse. Helical thickenings are occasionally present in axial parenchyma cells.-Rays are 2-3-seriate. The ray cells are procumbent, with several rows of square or upright marginal ray cells. Rays are $2,050(1,500-2,550) \mu \mathrm{m}$ high. The number of rays per mm varies from 19 to 27 .- Raphides are absent.
Pauridiantha Hook.f. (3 species/3 specimens examined)-Fig. 41.

Growth rings are indistinct.-Vessels are diffuse, solitary, or in short radial multiples. Mean vessel grouping index is 2.5 in $P$. viridiflora, but 1.5 and 1.4 in $P$. pyramidata and $P$. rubens respectively. The tangential diameter of vessel lumina averages $47(30-65) \mu \mathrm{m}$. Mean number of vessels per $\mathrm{mm}^{2}$ is $42(17-78)$. Vessel element perforations are simple. Intervessel pits are alternate, minute, and vestured. Vessel-ray pits are similar to intervessel pits. Mean vessel element length is $733(350-1,100) \mu \mathrm{m}$.-Fibre-tracheids are non-septate, with numerous distinctly bordered pits on radial and tangential fibre walls. Mean fibre length is $1,355(1,000-$ $1,900) \mu \mathrm{m}$.-Axial parenchyma is diffuse to diffuse-in-aggregates. Axial parenchyma strands are composed of 8 to 12 cells. Helical thickenings in axial parenchyma cells are rarely observed in $P$. pyramidata.-Rays are 2-3-seriate and up to 5-seriate in $P$. viridiflora. The ray cells are procumbent, with several rows of square or upright marginal ray cells. Rays are 1,304 (200-3,200) $\mu \mathrm{m}$ high. The number of rays per $\mathrm{mm}$ varies from 7 to 19.--Raphides are absent in the secondary xylem of the specimens studied.

Poecilocalyx Bremek. (2 species/2 specimens examined)

Growth rings are indistinct.-Vessels are diffuse and nearly always solitary. Mean vessel grouping index is 1.15. The tangential diameter of vessel lumina is small, on average 18 (10-25) $\mu \mathrm{m}$. Mean number of vessels per $\mathrm{mm}^{2}$ is $105(50-$ 164). Vessel element perforations are simple. Intervessel pits are alternate, minute, and vestured. Vessel-ray pits are similar to intervessel pits. Mean vessel element length is 719 (500-1,000) $\mu \mathrm{m}$.-Fibre-tracheids are non-septate, with numerous distinctly bordered pits on radial and tangential fibre walls. Mean fibre length is 1,108 (700-1,600) $\mu \mathrm{m}$. -Axial parenchyma is diffuse to diffuse-in-aggregates. Helical thickenings in axial parenchyma cells are occasionally found in P. stipulosa. Axial parenchyma strands are composed of 6 to 15 cells.-Rays are 2- to 4-seriate. The body ray cells are procumbent, with several rows of square or upright marginal ray cells. Rays average 1,480 (800$2,100) \mu \mathrm{m}$ high. The number of rays per $\mathrm{mm}$ varies from 10 to 24.-Raphides are absent.

Stelechantha Bremek. (1 species/1 specimen examined)-Fig. 40.

Growth rings are indistinct.-Vessels are diffuse, solitary or in short radial multiples. The mean vessel grouping index is 1.5. The tangential diameter of vessel lumina is small, averaging 21 (20-25) $\mu \mathrm{m}$ (Fig. 40). Mean number of vessels per $\mathrm{mm}^{2}$ is $82(60-110)$. Vessel element perforations are simple. Intervessel pits are alternate, minute, and vestured. Vessel-ray pits are similar to intervessel pits. Vessel element length is $850(650-1,100) \mu \mathrm{m}$.-Fibre-tracheids are non-septate, with numerous distinctly bordered pits on radial and tangential fibre walls. Mean fibre length is 1,432 (1,300$1,650) \mu \mathrm{m}$.-Axial parenchyma is scanty paratracheal or diffuse-in-aggregates (Fig. 41). Axial parenchyma strands are composed of 6 to 16 cells.-Rays are biseriate. The 

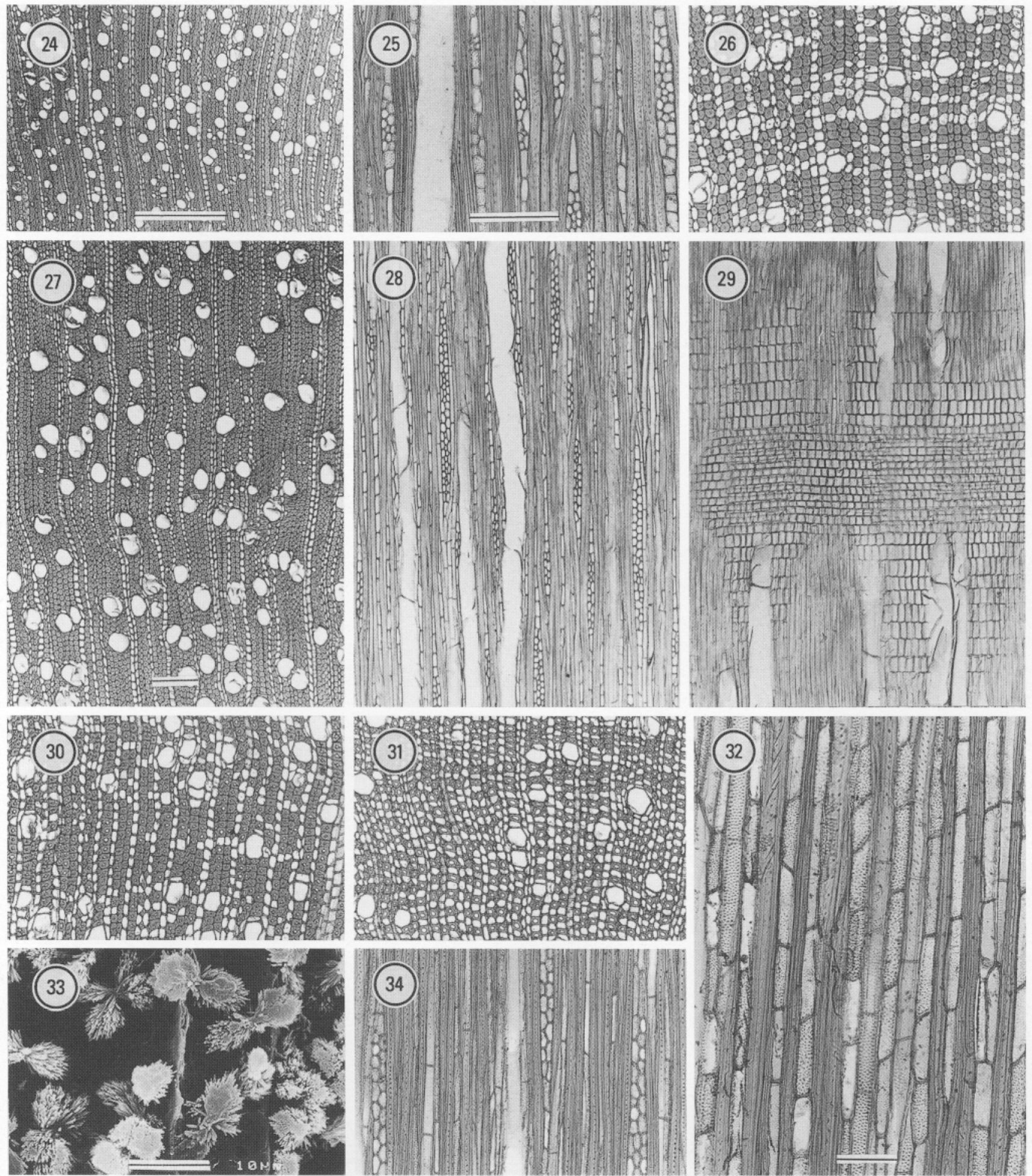

Figs. 24-34. Wood of Prismatomerideae (24-29) and Lasianthus (30-34). 24-32, 34: Light micrographs. 33: Scanning electron micrograph. 24: Prismatomeris sp. Transverse section (bar $=500 \mu \mathrm{m}$ ). 25: Prismatomeris sp. Tangential section (bar $=200 \mu \mathrm{m}$ ). 26: Rennellia elliptica. Transverse section with axial parenchyma diffuse to diffuse-in-aggregates (bar as in 25). 27-29: Rennellia sp. 27: Transverse section showing solitary vessels $(\mathrm{bar}=200 \mu \mathrm{m})$. 28: Tangential section (bar as in 27). 29: Radial section with procumbent or square body ray cells and several rows of upright/square marginal cells (bar as in 27). 30. Lasianthus sp. (Nooteboom 4034). Transverse section (bar as in 25). 31. Lasianthus sp. (Nooteboom 4026). Transverse section with axial parenchyma strands grouped in short tangential lines (bar as in 25). 32: Lasianthus acuminatus. Tangential section showing $1(-2)$-seriate rays $(b a r=100 \mu \mathrm{m})$. 33: Lasianthus scabridus. Detail of raphide-like crystal complexes $(\mathrm{bar}=10 \mu \mathrm{m}$ ). 34: Lasianthus sp. (Nooteboom 4026). Tangential section with 2-3-seriate rays and pits on tangential fibre walls (bar as in 25). 

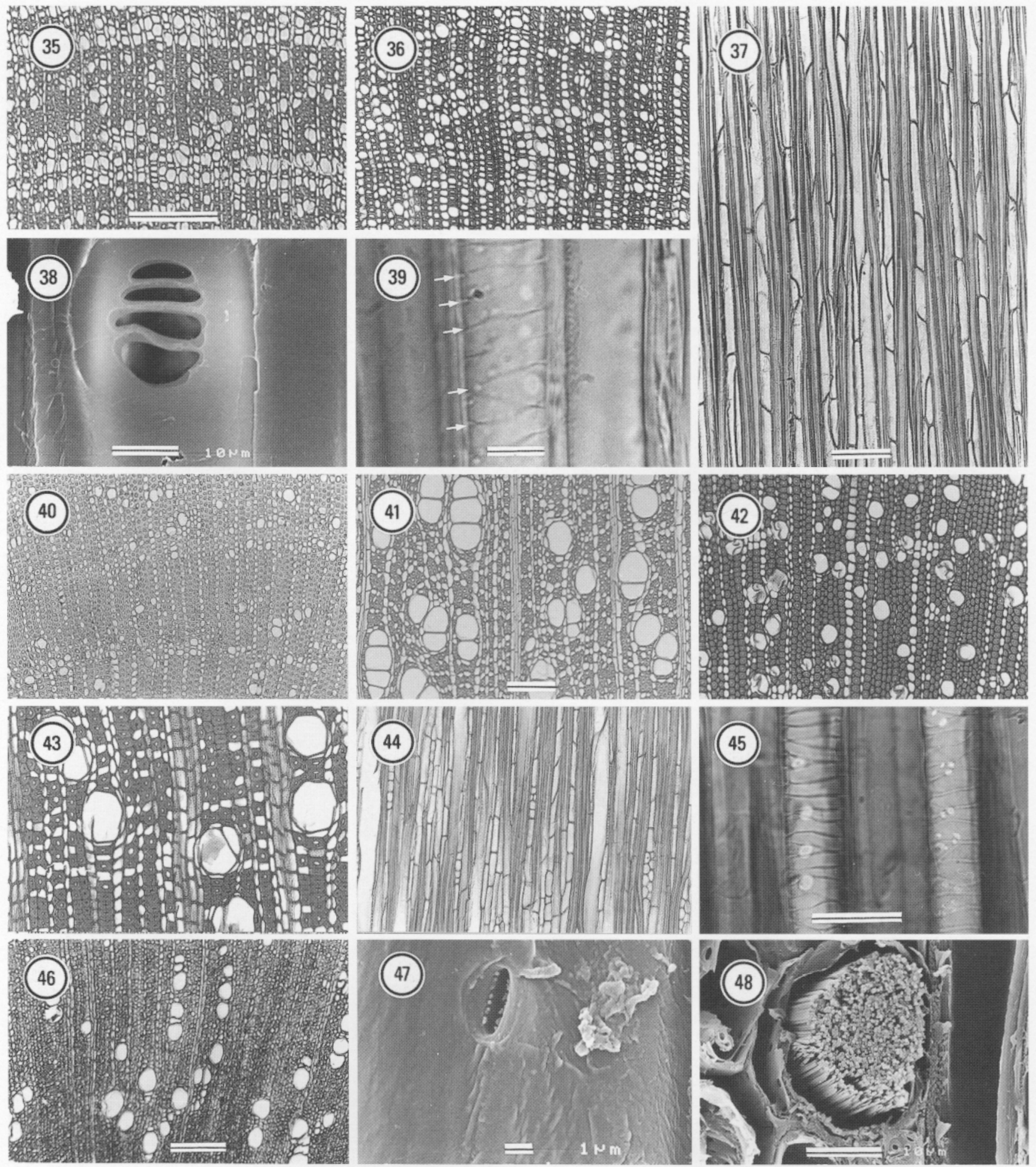

Figs. 35-48. Wood of Saldinia, Trichostachys, Pauridiantheae, Urophylleae, and Triainolepis. 35-37, 39-46: Light micrographs. 38, 47, 48: Scanning electron micrographs. 35: Saldinia sp. (Rakoto 307). Transverse section (bar $=200 \mu \mathrm{m}$ ). 36-39: Trichostachys microcarpa (Devred 7678). 36: Transverse section (bar as in 35). 37: Tangential section with 1(-2)-seriate rays (bar $=100 \mu \mathrm{m}$ ). 38: Scalariform perforation plate with three bars (bar $=10 \mu \mathrm{m}$ ). 39: Helical thickenings (arrows) in axial parenchyma cell with simple pits variable in size (bar $=10 \mu \mathrm{m}$ ). $40:$ Stelechantha makakana. Transverse section (bar as in 35). 41: Pauridiantha viridiflora. Transverse section (bar $=200 \mu \mathrm{m}$ ). 42: Urophyllum trifurcum. Transverse section (bar as in 35). 43. Maschalocorymbus corymbus. Transverse section (bar as in 35). 44: Urophyllum trifurcum. Tangential section (bar as in 35). 45: Urophyllum macrophyllum illustrating helical thickenings in two axial parenchyma cells with simple pits that are variable in size $(\mathrm{bar}=20 \mu \mathrm{m})$. 46: Triainolepis emirensis. Transverse section $(\mathrm{bar}=200 \mu \mathrm{m})$. 47-48: Triainolepis africana subsp. hildebrandtii $($ Gillet \& Kibuwa 19850). 47: Bordered fibre pit with minute vestures viewed from the outer surface $(b a r=1 \mu \mathrm{m})$. 48 . Raphide bundle in ray parenchyma cell (bar $=10 \mu \mathrm{m})$. 
body ray cells are procumbent, with several rows of square or upright marginal ray cells. Rays are 1,860 (1,500-3,000) $\mu \mathrm{m}$ high. The number of rays per $\mathrm{mm}$ varies from 21 to 30 . -Raphides are absent.

\section{Prismatomerideae Ruang}

Prismatomeris Thwaites (4 species/4 specimens)-Figs. 24, 25.

Growth rings are absent.-Vessels are diffuse and exclusively solitary (Fig. 24). Mean tangential vessel diameter is $36(15-75) \mu \mathrm{m}$ and narrow vessel elements that resemble vascular tracheids are common. The number of vessels per $\mathrm{mm}^{2}$ is $50(27-85)$. Vessel element length is highly variable $(300-2,300 \mu \mathrm{m})$; relatively long in $P$. sp. and $P$. beccariana, but shorter in $P$. brachypus and $P$. tetrandra. Vessel element perforations are always simple. All vessel pits are alternate, minute or small, and vestured.-Fibre-tracheids show bordered pits on radial and tangential walls (Fig. 25). Fibre length is about $2,000 \mu \mathrm{m}$, but much shorter in $P$. brachypus (on average $975 \mu \mathrm{m}$ ) and $P$. tetrandra (on average $713 \mu \mathrm{m}$ ). -Axial parenchyma is sparsely diffuse (Fig. 24) to diffuse-inaggregates. Axial parenchyma strands are composed of ca. seven to ten cells.-Rays are 1-2-(3)-seriate, heterogeneous (Fig. 25), and composed of upright/square ray cells with procumbent body ray cells. Perforated ray cells with simple perforations are present. Rays are more than $1 \mathrm{~mm}$ high and on average 14 (9-22) rays occur per mm.-Raphides are found in $P$. beccariana (Jacobs 5423).

Rennellia Korth. (2 species/2 specimens examined)-Figs. 26-29.

Growth rings are absent.-Vessels are diffuse and exclusively solitary (Figs. 26, 27). Vessel outline is round to oval. Vessel diameter averages $67(33-100) \mu \mathrm{m}$ and vessel frequency is $25(12-39)$ per $\mathrm{mm}^{2}$. Mean vessel element length is $1,110(650-1,450) \mu \mathrm{m}$. Vessel element perforations are simple. All vessel pits are alternate, minute, and vestured. -Fibre-tracheids are non-septate with distinctly bordered pits on radial and tangential walls. Fibre length is 1,765 $(1,500-2,280) \mu \mathrm{m}$.-Axial parenchyma is diffuse to diffuse-inaggregates (Fig. 26), and also scanty paratracheal in $R$. sp. (Fig. 27). Axial parenchyma strands are composed of 7 to 10 cells. - The heterogeneous rays are 2-3-seriate (Fig. 28) and composed of upright/square ray cells with few procumbent cells (Fig. 29). Rays are 1,450 (400-3,700) $\mu \mathrm{m}$ high and about 15 rays occur per mm.-Raphides are observed in $R$. elliptica, while small spiny druses are recorded in $R$. sp.

Triainolepideae Bremek.

Triainolepis Hook.f. (1 species/2 specimens examined)_Figs. 46-48 (T. emirensis is illustrated in Fig. 46 but not included in the description below).

Growth rings are indistinct.-Vessels are diffuse, solitary, grouped in relatively long radial multiples, or sometimes with a slight tendency to form a diagonal pattern (Fig. 46). The mean vessel grouping index is 2.7. Tangential vessel diameter averages $38(20-60) \mu \mathrm{m}$ and narrow vessel elements with a single, small perforation are common. Vessel density averages $55 / \mathrm{mm}^{2}$. Vessel element length averages 372 (200-550) $\mu \mathrm{m}$. Vessel element perforations are simple. Intervessel pits and vessel-ray pits are minute, alternate, and vestured.-Fibres are non-septate. The fibre pits are distinctly bordered, vestured (Fig. 47) and less common on tangential than on radial fibre walls. Fibre length is 666 $(250-1,100) \mu \mathrm{m}$.-Axial parenchyma is diffuse to diffuse-inaggregates. Axial parenchyma strands are composed of five to ten cells. - The heterogeneous rays are 2-3-seriate. Ray height is ca. $1,225 \mu \mathrm{m}$ and the mean number of rays per $\mathrm{mm}$ is 16.-Raphides are present in enlarged ray cells (Fig. 48).

\section{Urophylleae Bremek. ex Verdc.}

Leucolophus Bremek. (1 species/1 specimen examined)

Growth rings are indistinct.-Vessels are diffuse, exclusively solitary, and round to oval. The tangential diameter of vessel lumina averages $50(25-70) \mu \mathrm{m}$. Mean number of vessels per $\mathrm{mm}^{2}$ is 29 (24-35). Vessel element perforations are simple. All vessel pits are alternate, minute, and vestured. Mean vessel element length is $881(650-1,150) \mu \mathrm{m}$. -Fibre-tracheids are non-septate, with numerous distinctly bordered pits on radial and tangential fibre walls. Mean fibre length is $2,018(1,600-2,300) \mu \mathrm{m}$.-Axial parenchyma cells are diffuse-in-aggregate. Axial parenchyma strands are composed of 5 to 15 cells. Helical thickenings in axial parenchyma cells are ocassionally present.-Rays are 4-5seriate with sheath cells partly surrounding the rays. The ray cells are procumbent, with several rows of square or upright marginal ray cells. Rays are 1,954 (900-2,500) $\mu \mathrm{m}$ high. The number of rays per $\mathrm{mm}$ varies from 6 to 8 . -Raphides are absent.

Maschalocorymbus Bremek. (2 species/2 specimens examined)-Fig. 43.

Growth rings are absent.-Vessels are solitary or in short radial multiples. The mean vessel grouping index is 1.25 . The tangential diameter of vessel lumina averages 82 (50115) $\mu \mathrm{m}$; narrow vessels about $40 \mu \mathrm{m}$ wide are occasionally present. Mean number of vessels per $\mathrm{mm}^{2}$ is 24 (12-37). Vessel element perforations are simple. Intervessel pits are alternate, minute, and vestured. Vessel-ray pits are similar to intervessel pits. Mean vessel element length is 1,273 (600-1,700) $\mu \mathrm{m}$.-Fibre-tracheids are non-septate, with numerous distinctly bordered pits on radial and tangential fibre walls. Mean fibre length is $2,038(1,600-2,900) \mu \mathrm{m}$. -Axial parenchyma cells are diffuse to diffuse-in-aggregates and scanty paratracheal in M. corymbus (Fig. 43). Axial parenchyma strands are composed of 10 to 20 cells. -Rays are relatively homogeneous, 4-5-seriate and up to 6 -seriate in $M$. corymbus. The body ray cells are procumbent, with several rows of square or upright marginal ray cells. Rays are 1,948 $(900-3,200) \mu \mathrm{m}$ high. The number of rays per $\mathrm{mm}$ varies from 4 to 13.-Raphides are absent.

Pleiocarpidia Schumann. (2 species/2 specimens examined) Growth rings are absent or indistinct.-Vessels are solitary in $P$. sandahanica, but also in short radial multiples in $P$. 
pilosa. The tangential diameter of vessel lumina is relatively wide, on average $95(45-140) \mu \mathrm{m}$. Mean number of vessels per $\mathrm{mm}^{2}$ is $24(12-38)$. Vessel element perforations are simple. Vessel pits are alternate, minute, and vestured. Vessel-ray pits are similar to intervessel pits. Mean vessel element length is $1,300(800-1,800) \mu \mathrm{m}$.-Fibre-tracheids are non-septate, with numerous distinctly bordered pits on radial and tangential fibre walls. Mean fibre length is $1,945(1,400-$ $2,450) \mu \mathrm{m}$.-Axial parenchyma cells are diffuse or scanty paratracheal in $P$. sandahanica. Axial parenchyma strands are composed of 5 to 14 cells. Helical thickenings occur sparsely in axial parenchyma cells of $P$. sandahanica.-Rays are relatively homogeneous. They are 3-4-5-seriate. The ray cells are procumbent, with one row of square or upright marginal ray cells. Rays are $1,568(600-2,500) \mu \mathrm{m}$ high. The number of rays per $\mathrm{mm}$ varies from 6 to 11.-Raphides are absent.

\section{Praravinia Korth. (2 species/2 specimens examined)}

Growth rings are absent or indistinct.-Vessels are nearly always solitary. Mean vessel grouping index is 1.2. The tangential diameter of vessel lumina averages 51 (30-70) $\mu \mathrm{m}$. Mean number of vessels per $\mathrm{mm}^{2}$ is 61 (28-120). Vessel element perforations are simple. Intervessel pits are alternate, minute, and vestured. Vessel-ray pits are similar to intervessel pits. Mean vessel element length is 1,077 (7001,500) $\mu \mathrm{m}$.-Fibre-tracheids are non-septate, with numerous distinctly bordered pits on radial and tangential fibre walls. Mean fibre length is $1,664(1,100-2,120) \mu \mathrm{m}$.-Axial parenchyma cells are diffuse to diffuse-in-aggregates. Axial parenchyma strands are composed of 6 to 15 cells. Helical thickenings in axial parenchyma cells are observed in the specimens of Praravinia studied.-Rays are relatively homogeneous. They are uniseriate or biseriate in $P$. suberosa, but 4-5-seriate in $P$. sp. The body ray cells are procumbent, with several rows of square or upright marginal ray cells. Rays are $1,477(900-2,800) \mu \mathrm{m}$ high. The number of rays per $\mathrm{mm}$ varies from 4 to 18.-Raphides are absent.

Urophyllum Jack ex Wallich. (4 species/4 specimens examined)-Figs: 42, 44, 45.

Growth rings are absent or indistinctly present.-Vessels are exclusively solitary in U. trifurcum (Fig. 42), but also in short radial multiples in the other species studied. Vessel grouping index is 1.5 in U. zeylanicum, U. macrophyllum and 2.5 in $U$. corymbosum. The tangential diameter of vessel lumina averages $58(20-70) \mu \mathrm{m}$. Mean number of vessels per $\mathrm{mm}^{2}$ is 57 (30-90). Vessel element perforations are simple. Intervessel pits are alternate, minute, and vestured. Vessel-ray pits are similar to intervessel pits. Mean vessel element length is $1,000(700-1,500) \mu \mathrm{m}$.-Fibre-tracheids are non-septate, with numerous distinctly bordered pits on radial and tangential fibre walls. Mean fibre length is $1,542(1,000-$ $2,000) \mu \mathrm{m}$.-Axial parenchyma is diffuse to diffuse-in-aggregates. Axial parenchyma strands are composed of 4 to 11 cells, with occasional helical thickenings in U. cf. macrophyllum (Fig. 45) and U. corymbosum.-Rays are 2-3-seriate but mainly uniseriate in $U$. trifurcum (Fig. 44). The ray cells are procumbent, with one row of square or upright marginal ray cells. Rays are $1,350(400-2,600) \mu \mathrm{m}$ high. The number of rays per $\mathrm{mm}$ varies from 10 to 22.-Raphides are absent.

\section{Lasianthus group}

Lasianthus Jack ( 6 species/6 specimens examined)-Figs. 30-34.

Growth rings are indistinct; marked by marginal parenchyma in L. batangensis and L. mayumbensis. - Vessels are diffuse, mainly solitary, and the mean vessel grouping index is 1.23. Higher vessel grouping indices occur in L. batangensis (1.6) and L. scabridus (1.4). Vessel outline is circular to oval. Tangential vessel diameter is $33(20-52) \mu \mathrm{m}$; wider vessels $70(40-100) \mu \mathrm{m}$ are observed in L. batangensis. Vessel density averages $75 / \mathrm{mm}^{2}$. Vessel element length averages $1,020(400-1,700) \mu \mathrm{m}$. Vessel element perforations are simple. Intervessel pits are minute, alternate, and vestured.-Fibre-tracheids are non-septate and the bordered pits on radial and tangential walls (Fig. 34) are sometimes vestured. Fibre length is 1,612 (1,200-2,300) $\mu \mathrm{m}$.-Axial parenchyma is diffuse to diffuse-in-aggregates (Fig. 30, 31). Axial parenchyma strands are composed of five to ten cells. Axial parenchyma cells that show helical thickenings with vestured pits are sporadically found in $L$. sp. $(4026,4034$, 4189). - The heterogeneous rays are 1-2-seriate with the 2seriate portion generally not much wider than the uniseriate portions (Fig. 32). Triseriate rays are recorded for $L$. sp. (4026, 4034; Fig. 34) and L. batangensis (Tw 33582). Mean height of the rays is $2,000 \mu \mathrm{m}$ and about 15 rays per $\mathrm{mm}$ occur. The rays are composed of procumbent cells with marginal rows of upright/square cells. Perforated ray cells are common. Perforations of perforated ray cells are simple, but scalariform with more than 10 bars in $L$. cinereus and $L$. acuminatus.-Raphides are present in L. cinereus, $L$. scabridus (Fig. 33), and L.sp. (4189); they are frequently composed of two bundles of needie-like crystals forming raphide complexes. Pith flecks are observed in L. batangensis (Tw 33582).

Saldinia A. Rich. ex DC. (1 species/2 specimens examined) -Fig. 35.

Growth rings are indistinct.-The vessels are diffuse, mainly solitary, and vessel grouping index is 1.3. The mean vessel diameter is $22(20-30) \mu \mathrm{m}$ and the number of vessels per $\mathrm{mm}^{2}$ is $215(200-240)$. Vessel element length is 1,018 (640-1,350) $\mu \mathrm{m}$. Vessel element perforations are simple and occasionally scalariform in the specimen collected by Lewis and Razafimandimbison (nr. 723), but entirely scalariform in the other specimen studied (Rakoto 301). Intervessel pits and vessel-ray pits are minute, alternate, and vestured. -Fibres show distinctly bordered pits on tangential and radial walls. Fibres are non-septate. Mean fibre length is $1,583(900-2,400) \mu \mathrm{m}$.-Axial parenchyma is diffuse (Fig. 35). - The juvenile rays are heterogeneous and uniseriate. -Mineral inclusions are not observed in the secondary xylem. 
Table 2a. List of wood anatomical features. Numbers in parentheses are averages. $1=$ vessel grouping index; $2=$ perforation plates simple; $3=$ perforation plates scalariform; $4=$ intervessel pits minute ; $5=$ intervessel pits small $(>4 \mu \mathrm{m}) ; 6=$ vessel-ray pitting with distinct borders ; $7=$ vessel-ray pitting with reduced borders; $8=$ tangential diameter of vessel lumina $(\mu \mathrm{m}) ; 9=$ vessels $/ \mathrm{mm}^{2} ; 10=$ vessel element length $(\mu \mathrm{m}) ; 11=$ fibre pits simple to minutely bordered; $12=$ fibre pits distinctly bordered; $13=$ fibre pits on radial and tangential walls ; $14=$ septate fibres ; $15=$ fibre length $(\mu \mathrm{m}) ;+=$ present ; $-=$ absent ; ?=unknown

\begin{tabular}{|c|c|c|c|c|c|c|c|c|c|c|c|c|c|c|c|}
\hline & 1 & 2 & 3 & 4 & & 5 & 6 & 8 & 9 & 10 & 11 & 12 & 13 & 14 & 15 \\
\hline Declieuxia fruticosa & 1.23 & + & - & + & - & + & - & $17-(21)-30$ & $120-160$ & $370-(436)-510$ & + & - & - & + & $500-(585)-620$ \\
\hline Hindsia Iongiflora & 1.76 & + & - & + & - & + & - & $17-(20)-30$ & $100-120$ & $300-(371)-450$ & + & - & - & + & $500-(598)-700$ \\
\hline Coussarea af. grandis & 1.3 & + & - & + & - & + & - & $50-(61)-70$ & $24-(30)-39$ & $900-(1020)-1250$ & + & - & - & - & $1490-(1634)-2000$ \\
\hline C. contracta & 1.51 & + & - & + & - & + & - & $30-(48)-60$ & $36-(47)-56$ & $690-(908)-1000$ & + & - & - & + & $1100-(1490)-1800$ \\
\hline C. hirticalyx & 2.15 & + & - & - & + & + & - & $33-(49)-65$ & $24-(36)-48$ & $800-(907)-1100$ & + & - & - & + & $800-(1428)-2090$ \\
\hline C. leptoloba & 2.16 & + & - & - & + & + & - & $40-(47)-65$ & $40-(52)-64$ & $870-(1115)-1300$ & + & - & - & + & $1180-(1600)-1900$ \\
\hline C. machadoana & 1.6 & + & - & + & + & + & - & $30-(40)-50$ & $42-(46)-52$ & $800-(1158)-1400$ & + & - & - & + & $1700-(2040)-2400$ \\
\hline C. megalocarpa & 1.54 & + & - & + & + & + & - & $34-(42)-55$ & $34-(41)-56$ & $700-(884)-1200$ & + & - & - & + & $1200-(1488)-1750$ \\
\hline C. ovalis & 1.3 & + & - & + & - & + & - & $37-(52)-59$ & $50-(62)-90$ & $600-(955)-1200$ & + & - & - & + & $1150-(1395)-1800$ \\
\hline C. quatracasasii & 1.21 & + & - & + & - & + & - & $30-(43)-65$ & $16-(23)-34$ & $950-(1267)-1500$ & + & - & - & + & $1500-(1912)-2200$ \\
\hline C. surinamensis & 2.14 & + & - & + & + & + & - & $35-(46)-60$ & $50-(56)-70$ & $700-(1084)-1300$ & + & - & - & + & $1500-(1734)-1950$ \\
\hline C. tenuiflora & 1.83 & + & - & + & - & + & - & $30-(38)-48$ & $60-(85)-120$ & $600-(802)-1100$ & + & - & - & + & $1200-(1372)-1650$ \\
\hline C. vallis & 1.45 & + & - & - & + & - & + & $80-(116)-150$ & $15-(17)-22$ & $1000-(1153)-1450$ & + & - & - & + & $1760-(2081)-2400$ \\
\hline Faramea amplifolia & 1.29 & + & - & + & - & + & - & $30-(43)-57$ & $40-(48)-54$ & $700-(990)-1200$ & + & - & - & + & $1400-(1713)-1950$ \\
\hline F. anisocalyx & 1.6 & + & - & + & + & + & - & $30-(46)-60$ & $24-(35)-50$ & $800-(883)-1000$ & + & - & - & + & $1050-(1280)-1400$ \\
\hline F. elegans & 1.3 & + & - & + & - & + & - & $41-(50)-63$ & $43-(47)-52$ & $800-(1033)-1300$ & + & - & - & + & $1400-(1675)-2000$ \\
\hline F. glandulosa & 1.98 & + & - & + & - & + & - & $20-(44)-60$ & $70-(81)-100$ & $500-(972)-1120$ & + & - & - & + & $1050-(1600)-1900$ \\
\hline F. neblinae & 1.5 & + & - & + & - & + & - & $37-(47)-56$ & $37-(44)-55$ & $800-(970)-1100$ & + & - & - & + & $1200-(1474)-1600$ \\
\hline F. occidentalis & 1.4 & + & - & + & - & + & - & $48-(58)-74$ & $38-(48)-59$ & $420-(855)-1250$ & + & - & - & + & $1300-(1590)-2000$ \\
\hline F. parvibracteata & 2.76 & + & - & + & - & + & - & $20-(44)-60$ & $80-(93)-110$ & $500-(895)-1300$ & + & - & - & + & $900-(1305)-1600$ \\
\hline F. quadricostata & 1.4 & + & - & + & - & + & - & $18-(28)-37$ & $61-(74)-93$ & $650-(767)-1100$ & + & - & - & + & $900-(1205)-1400$ \\
\hline F. rectinervis & 1.1 & + & - & + & - & + & - & $37-(50)-60$ & $37-(51)-62$ & $400-(500)-650$ & + & - & - & + & $730-(1006)-1260$ \\
\hline F. stenopetala & 1.76 & + & - & + & - & + & - & $40-(52)-70$ & $40-(52)-70$ & $500-(762)-950$ & + & - & - & + & $1100-(1496)-1820$ \\
\hline F. warminigiana & 1.6 & + & - & + & - & + & - & $42-(49)-56$ & $42-(49)-56$ & $600-(717)-850$ & + & - & - & + & $1100-(1280)-1500$ \\
\hline $\begin{array}{l}\text { Craterispermum } \\
\text { cerinanthum } \\
\text { (Tw 41594) }\end{array}$ & 1.18 & + & - & + & - & + & - & $45-(64)-80$ & $23-(30)-38$ & $840-(914)-1200$ & - & + & + & - & $1600-(1900)-2250$ \\
\hline $\begin{array}{l}\text { C. cerinanthum } \\
\text { (Tw 48567) }\end{array}$ & 1.35 & + & - & + & - & + & - & $35-(48)-65$ & $11-(56)-68$ & $600-(910)-1150$ & - & + & + & - & $1300-(1522)-1700$ \\
\hline C. laurinum & 1.2 & + & - & + & - & + & - & $40-(66)-90$ & $20-(21)-23$ & $1000-(1170)-1500$ & - & + & + & - & 1650)-1942)-2200 \\
\hline C. schweinfurthii & 1.11 & + & - & + & - & + & - & $25-(42)-58$ & $58-(39)-50$ & $600-(850)-1180$ & - & + & + & - & $1000-(1356)-1650$ \\
\hline Damnacanthus indicus & $?$ & + & - & + & - & + & - & $20-(24)-27$ & $?$ & $600-(693)-900$ & + & - & + & + & $700-(906)-1000$ \\
\hline Gynochtodes sp. & 1.12 & + & - & - & + & + & - & $160-(248)-340$ & $5-(7)-10$ & $350-(450)-600$ & - & + & + & - & $800-(905)-1100$ \\
\hline G. coriacea & 1 & + & - & - & + & + & - & $150-(246)-300$ & $4-(5)-8$ & $300-(410)-500$ & - & + & + & - & $700-(843)-1000$ \\
\hline Morinda angustifolia & 1.97 & + & - & - & + & + & - & $20-(53)-85$ & $24-(27)-34$ & $500-(670)-800$ & - & + & + & - & $1100-(1335)-1600$ \\
\hline M. citrifolia & 1.46 & + & - & + & + & + & - & $50-(65)-90$ & $27-(40)-52$ & $400-(670)-950$ & - & + & + & - & $1050-(1360)-1600$ \\
\hline M. citrifolia (Tw 46621) & 2.2 & + & - & - & + & + & - & $50-(89)-120$ & $11-(18)-23$ & $300-(390)-500$ & - & + & + & - & $1100-(1290)-1400$ \\
\hline M. debilis & 1.19 & + & - & + & - & + & - & $20-(28)-35$ & $21-(31)-43$ & $300-(405)-500$ & - & + & + & - & $620-(784)-900$ \\
\hline M. geminata & 1.83 & + & - & - & + & + & - & $50-(110)-160$ & $3-(10)-15$ & $300-(510)-700$ & + & - & - & - & $1250-(1629)-1950$ \\
\hline M. lucida & 2 & + & - & - & + & + & - & $60-(86)-115$ & $11-(19)-24$ & $150-(300)-400$ & - & + & + & - & $580-(750)-900$ \\
\hline $\begin{array}{l}\text { M. morindoides } \\
\left(U_{W} 9264\right)\end{array}$ & 1.1 & + & - & - & + & - & + & $150-(240)-350$ & $5-(6)-8$ & $150-(278)-450$ & - & + & + & - & $650-(898)-1030$ \\
\hline M. morindoides & 1.08 & + & - & - & + & - & + & $35-(68)-120$ & $22-(29)-36$ & $410-(484)-700$ & - & + & + & - & $600-(678)-850$ \\
\hline M. myrtifolia & 1 & + & - & + & + & + & - & $50-(64)-80$ & $38-(45)-56$ & $800-(1060)-1300$ & - & + & + & - & $1000-(1345)-1800$ \\
\hline M. reticulata & 1.28 & + & - & - & + & - & + & $70-(143)-220$ & $16-(18)-24$ & $200-(415)-550$ & $?$ & $?$ & $?$ & $?$ & $600-(710)-800$ \\
\hline $\begin{array}{l}\text { Commitheca } \\
\text { liebrechtsiana }\end{array}$ & 1.42 & + & - & + & - & + & - & $30-(39)-50$ & $52-(66)-80$ & $600-(841)-1100$ & - & + & + & - & $800-(1273)-1600$ \\
\hline
\end{tabular}


Table 2a. Continued

\begin{tabular}{|c|c|c|c|c|c|c|c|c|c|c|c|c|c|c|c|}
\hline & 1 & 2 & 3 & 4 & & 5 & 6 & 8 & 9 & 10 & 11 & 12 & 13 & 14 & 15 \\
\hline Pauridiantha viridiflora & 2.5 & + & - & + & - & + & - & $33-(45)-65$ & $17-(24)-31$ & $650-(866)-1100$ & - & + & + & - & $1300-(1573)-1900$ \\
\hline P. pyramidata & 1.5 & + & - & + & - & + & - & $30-(48)-65$ & $60-(66)-78$ & $350-(740)-1000$ & - & + & + & - & $1000-(1285)-1600$ \\
\hline P. rubens & 1.38 & + & - & + & - & + & - & $40-(48)-60$ & $31-(38)-46$ & $400-(592)-720$ & - & + & + & - & $1100-(1206)-1500$ \\
\hline Poecilocalyx schumannii & 1.18 & + & - & + & - & + & - & $10-(20)-25$ & $136-(146)-164$ & $500-(644)-800$ & - & + & + & - & $700-(850)-1000$ \\
\hline P. stipulosa & 1.12 & + & - & + & - & + & - & $12-(16)-25$ & $50-(65)-100$ & $550-(795)-1000$ & - & + & + & - & $1100-(1367)-1600$ \\
\hline Stelechantha makakana & 1.5 & + & - & + & - & + & - & $20-(21)-25$ & $60-(82)-110$ & $650-(850)-1100$ & - & + & + & - & $1300-(1432)-1650$ \\
\hline Prismatomeris sp. & 1 & + & - & - & + & + & - & $40-(55)-75$ & $41-(47)-55$ & $1100-(1630)-2300$ & - & + & + & - & $2000-(2290)-2700$ \\
\hline P. beccariana (5423) & 1 & + & - & + & - & + & - & $19-(23)-27$ & $40-(68)-85$ & $600-(925)-1100$ & - & + & + & - & $1600-(1810)-2100$ \\
\hline P. beccariana (4336) & 1 & + & - & + & + & + & - & $30-(50)-70$ & $46-(53)-62$ & $700-(1100)-1700$ & - & + & + & - & $2000-(2170)-2400$ \\
\hline P. brachypus & 1 & + & - & + & - & + & - & $15-(22)-30$ & $?$ & $300-(505)-700$ & - & + & + & - & $800-(975)-1200$ \\
\hline P. tetrandra & 1 & + & - & + & - & + & - & $22-(31)-36$ & $27-(33)-44$ & $300-(445)-700$ & - & + & + & - & $470-(713)-920$ \\
\hline Rennellia sp. & 1 & + & - & + & - & + & - & $50-(80)-100$ & $24-(33)-39$ & $650-(950)-1200$ & - & + & + & - & $1500-(1640)-1800$ \\
\hline R. elliptica & 1 & + & - & + & - & + & - & $33-(53)-100$ & $12-(16)-21$ & $1100-(1270)-1450$ & - & + & + & - & $1500-(1890)-2280$ \\
\hline $\begin{array}{l}\text { Triainolepis } \\
\text { africana } 1040 \text { (BR) }\end{array}$ & 3 & + & - & + & - & + & - & $22-(35)-50$ & $38-(64)-80$ & $200-(305)-350$ & - & + & + & - & $250-(545)-670$ \\
\hline T. africana (Tw 19850) & 2.4 & + & - & + & - & + & - & $20-(41)-60$ & $320-(440)-550$ & $320-(440)-550$ & - & + & + & - & $620-(788)-1100$ \\
\hline Leucolophus sp. & 1 & + & - & + & - & + & - & $25-(50)-70$ & $24-(29)-35$ & $650-(881)-1150$ & - & + & + & - & $1600-(2018)-2300$ \\
\hline Maschalocorymbus sp. & 1.6 & + & - & + & - & + & - & $70-(84)-115$ & $28-(31)-37$ & $600-(1246)-1700$ & - & + & - & - & $1800-(2198)-2900$ \\
\hline M. corymbus & 1.1 & + & - & + & - & + & - & $50-(79)-110$ & $12-(16)-19$ & $900-(1300)-1600$ & - & + & + & - & $1600-(1879)-2100$ \\
\hline $\begin{array}{l}\text { Pleiocarpidia sanda- } \\
\text { hanica }\end{array}$ & 1.1 & + & - & + & - & + & - & $85-(120)-140$ & $12-(17)-21$ & $1100-(1432)-1800$ & - & + & - & - & $1500-(2084)-2450$ \\
\hline P. pilosa & 1.8 & + & - & + & - & + & - & $45-(70)-100$ & $26-(31)-38$ & $800-(1163)-1400$ & - & + & - & - & $1400-(1807)-2150$ \\
\hline Praravinia sp. & 1.2 & + & - & + & - & + & - & $50-(67)-70$ & $28-(34)-42$ & $900-(1177)-1500$ & - & + & + & - & $1800-(1968)-2120$ \\
\hline P. suberosa & 1.2 & + & - & + & - & + & - & $30-(36)-40$ & $70-(88)-120$ & $700-(977)-1400$ & - & + & + & - & $1100-(1360)-1700$ \\
\hline $\begin{array}{l}\text { Urophyllum cf. } \\
\text { macrophyllum }\end{array}$ & 1.5 & + & - & + & - & + & - & $20-(31)-40$ & $58-(66)-80$ & $700-(857)-1100$ & - & + & + & - & $1200-(1447)-1750$ \\
\hline U. corymbosum & 2.5 & + & - & + & - & + & - & $40-(52)-70$ & $34-(37)-40$ & $900-(1014)-1$ & - & + & + & - & $1000-(1709)-2000$ \\
\hline U. trifurcum & 1 & + & - & + & - & + & - & $20-(32)-45$ & $65-(76)-90$ & $700-(908)-1100$ & - & + & + & - & $1200-(1369)-1600$ \\
\hline U. zeylanicum & 1.52 & + & - & + & - & + & - & $25-(32)-40$ & $30-(52)-60$ & $1100-(1225)-1500$ & - & + & + & - & $1400-(1642)-1900$ \\
\hline Lasianthus sp. (4026) & 1.33 & + & - & + & + & + & - & $22-(33)-45$ & $37-(50)-78$ & $700-(1075)-1400$ & - & + & + & - & $1550-(1840)-2200$ \\
\hline L. sp. (4034) & 1.03 & + & - & + & + & + & - & $25-(36)-47$ & $52-(60)-80$ & $900-(1270)-1450$ & - & + & + & - & $1300-(1730)-2100$ \\
\hline L. sp. (4189) & 1.09 & + & - & + & - & + & - & $26-(33)-38$ & $45-(60)-70$ & $850-(1280)-1700$ & - & + & + & - & $1650-(2070)-2300$ \\
\hline L. acuminatus & 1.21 & + & - & + & - & + & - & $27-(38)-50$ & $52-(71)-88$ & $500-(980)-1340$ & - & + & + & - & $1500-(1800)-2100$ \\
\hline L. batangensis & 1.6 & + & - & + & - & + & - & $40-(70)-100$ & $95-(100)-106$ & $400-(722)-1000$ & - & + & + & - & $1000-(1130)-1300$ \\
\hline $\begin{array}{l}\text { L. batangensis } \\
\text { (Tw 33582) }\end{array}$ & 1.07 & + & - & + & - & + & - & $25-(34)-40$ & $55-(64)-85$ & $500-(856)-1200$ & - & + & + & - & $1200-(1496)-1700$ \\
\hline L. cinereus & 1.1 & + & - & + & - & + & - & $20-(28)-38$ & $(80)-94$ & $720-(850)-1000$ & - & + & + & - & $1200-(1300)-1600$ \\
\hline L. mayumbensis & 1.27 & + & - & + & - & + & - & $21-(27)-33$ & $50-(80)-100$ & $?$ & - & + & + & - & $?$ \\
\hline L. scabridus & 1.4 & + & - & + & + & + & - & $30-(38)-52$ & $100-(120)-130$ & $950-(1130)-1400$ & - & + & + & - & $1300-(1535)-1750$ \\
\hline Saldinia sp. $(307)$ & 1.2 & + & + & + & - & + & - & $15-(21)-30$ & $200-(218)-240$ & $940-(1150)-1350$ & - & + & + & + & $1600-(1883)-2400$ \\
\hline S. sp. $(723)$ & 1.4 & + & + & + & - & + & - & $20-(23)-30$ & $204-(211)-224$ & $640-(887)-1100$ & - & + & + & - & $940-(1150)-1350$ \\
\hline $\begin{array}{l}\text { Trichostachys } \\
\text { microcarpa (7678) }\end{array}$ & 1.21 & + & + & + & - & + & - & $16-(21)-30$ & $150-(170)-200$ & $670-(856)-1050$ & - & + & + & + & $680-(1070)-1310$ \\
\hline T. microcarpa (2883) & 1.38 & + & + & + & - & + & - & $20-(25)-30$ & $125-(150)-170$ & $600-(906)-1050$ & - & + & + & + & $1200-(1330)-1550$ \\
\hline
\end{tabular}


Table $2 b$. List of wood anatomical features. Numbers in parentheses are averages. $16=$ axial parenchyma scanty paratracheal ; 17=axial parenchyma diffuse; $18=$ axial parenchyma diffuse-in-aggregates; $19=$ axial parenchyma in narrow bands ; $20=$ axial parenchyma in wide bands ; $21=$ helical thickenings in axial parenchyma cells ; $22=$ ray width in cell numbers; $23=$ ray height $(\mu \mathrm{m}) ; 24=$ sheath cells (partly) surrounding rays; $25=$ rays $/ \mathrm{mm} ; 26=$ raphides ; $+=$ present; $-=$ absent ; ?=unknown

\begin{tabular}{|c|c|c|c|c|c|c|c|c|c|c|c|}
\hline & 16 & 17 & 18 & 19 & 20 & 21 & 22 & 23 & 24 & 25 & 26 \\
\hline Declieuxia fruticosa & - & - & - & - & - & - & $1-3$ & $1300-(1400)-1500$ & - & $12-13$ & + \\
\hline Hindsia longiflora & - & - & - & - & - & - & $1-2$ & $400-(950)-1700$ & - & $12-(13)-16$ & - \\
\hline Coussarea af. grandis & + & - & - & - & - & - & $1,4-6$ & $2000-(3897)-8300$ & + & $7-(9)-10$ & - \\
\hline C. contracta & + & - & - & - & - & - & $1,4-5$ & $600-(1166)-1900$ & + & $10-(12)-15$ & - \\
\hline C. hirticalyx & + & - & - & - & - & - & $1,5-6$ & $1200-(1945)-3200$ & + & $8-(9)-10$ & - \\
\hline C. leptoloba & + & - & - & - & - & - & $1,4-5$ & $1000-(2336)-4100$ & + & $14-(15)-17$ & - \\
\hline C. machadoana & + & - & - & - & - & - & $1,3-6$ & $1800-(3127)-5700$ & + & $8-(11)-14$ & + \\
\hline C. megalocarpa & + & - & - & - & - & - & $1,4-10$ & $2600-(5113)-10+00$ & + & $8-(10)-13$ & + \\
\hline C. ovalis & + & - & - & - & - & - & $1,5-8$ & $1110-(2134)-4070$ & + & $6-(6)-7$ & + \\
\hline C. quatracasasii & + & - & - & - & - & - & $1,4-5-(6)$ & $2250-(4305)-5700$ & + & $8-(10)-12$ & + \\
\hline C. surinamensis & + & - & - & - & - & - & $1,4-5$ & $1050-(3470)-7010$ & + & $7-(8)-10$ & + \\
\hline C. tenuiflora & + & - & - & - & - & - & $1,2,3$ & $300-(1140)-2200$ & - & $15-(17)-19$ & - \\
\hline C. vallis & + & - & - & - & - & - & 1,4 & $800-(1642)-3200$ & + & $7-(8.5)-10$ & + \\
\hline Faramea amplifolia & + & - & - & - & - & - & $1,4-5$ & $600-(1500)-2100$ & + & 9,10 & + \\
\hline F. anisocalyx & + & - & - & - & - & - & $1,4-6$ & $420-(1324)-2200$ & + & $8-(9)-10$ & - \\
\hline F. elegans & + & - & - & - & - & - & $1,2,3$ & $555-(1565)-2775$ & + & $13-(14)-17$ & - \\
\hline F. glandulosa & + & - & - & - & - & - & 4,6 & $1000-(1780)-2600$ & + & $10-(11)-12$ & + \\
\hline F. neblinae & + & - & - & - & - & - & $\begin{array}{l}1,5-10 \\
(16)\end{array}$ & $814-(2371)-5550$ & + & $6-(6)-8$ & - \\
\hline F. occidentalis & + & - & - & - & - & - & $1,5-6$ & $555-(1585)-2590$ & + & $6-(7)-8$ & + \\
\hline F. parvibracteata & + & - & - & - & - & - & $1,3-4$ & $800-(1413)-4000$ & + & $10-(12)-14$ & - \\
\hline F. quadricostata & + & - & - & - & - & - & $1,3-4$ & $370-(1804)-9620$ & + & $9-(10)-12$ & + \\
\hline F. rectinervis & + & - & - & - & - & - & $1,4-5(6)$ & $740-(1323)-2405$ & + & $8-(9)-10$ & + \\
\hline F. stenopetala & + & - & - & - & - & - & $1,4-7$ & $400-(1284)-2200$ & + & $10-(12)-13$ & - \\
\hline F. warminigiana & + & - & - & - & - & - & $1,4-7$ & $600-(1288)-2400$ & + & $11-(12)-13$ & - \\
\hline $\begin{array}{l}\text { Craterispermum cerinanthum } \\
\text { (Tw 41594) }\end{array}$ & - & - & - & - & + & - & $1,2,3$ & $400-(1553)-3300$ & - & $11-(14)-17$ & + \\
\hline C. cerinanthum ( $T w$ 48567) & - & - & - & - & + & - & 1,2 & $300-(1290)-2400$ & - & $14-(16)-17$ & + \\
\hline C. laurinum & - & - & - & - & + & - & $1,2,3$ & $900-(3142)-5010$ & - & $14-(15)-17$ & + \\
\hline C. schweinfurthii & - & - & - & - & + & - & 1,2 & $400-(912)-1500$ & - & $16-(18)-20$ & + \\
\hline Damnacanthus indicus & - & - & - & - & - & - & $1-(2)$ & $800-(1145)-1500$ & - & $?$ & - \\
\hline Gynochtodes sp. & - & - & - & - & + & - & $1-(2)$ & $150-(354)-700$ & - & $11-12$ & + \\
\hline G. coriacea & - & - & - & - & + & - & $1-(2)$ & $10-(227)-350$ & - & $12-(13)-14$ & + \\
\hline Morinda angustifolia & - & + & + & + & - & - & 2,3 & $200-(752)-1700$ & - & $8-(12)-17$ & - \\
\hline M. citrifolia & - & - & + & - & - & - & 2,3 & $700-(1315)-1800$ & - & $8-(10)-12$ & - \\
\hline M. citrifolia (Tw 4662T) & - & - & + & - & - & - & $3,4,5$ & $250-(564)-1100$ & - & $9-(11)-12$ & + \\
\hline M. debilis & - & - & - & + & + & - & 1 & $200-(550)-1400$ & - & $13-(15)-17$ & + \\
\hline M. geminata & - & - & - & - & + & - & $3,4,5$ & $150-(769)-1950$ & - & $9-(10)-11$ & - \\
\hline M. lucida & - & - & - & - & + & - & 2,3 & $100-(654)-1200$ & - & $9-(10)-11$ & - \\
\hline M. morindoides (Uw 9264) & - & - & - & - & + & - & 1,2 & $150-(377)-700$ & - & $12-(13)-14$ & + \\
\hline M. morindoides & + & - & - & + & - & - & $1,(2)$ & $200-(785)-2300$ & - & $7-(9)-13$ & - \\
\hline M. myrtifolia & - & + & + & + & - & - & $1,(2)$ & $210-(508)-800$ & - & $9-(10)-12$ & - \\
\hline M. reticulata & - & - & - & - & + & - & $?$ & $?$ & - & $?$ & + \\
\hline Commitheca liebrechtsiana & - & + & - & - & - & + & 2,3 & $1500-(2050)-2550$ & - & $19-(22)-27$ & \\
\hline
\end{tabular}


Table 2b. Continued

\begin{tabular}{|c|c|c|c|c|c|c|c|c|c|c|c|}
\hline & 16 & 17 & 18 & 19 & 20 & 21 & 22 & 23 & 24 & 25 & 26 \\
\hline Pauridiantha viridiflora & - & + & + & - & - & - & $3,4,5$ & $700-(1300)-2500$ & - & $7-(9)-10$ & - \\
\hline P. pyramidata & - & + & + & - & - & + & 2,3 & $200-(1487)-3200$ & - & $12-(17)-19$ & - \\
\hline P. rubens & - & + & - & - & - & - & 2,3 & $600-(1125)-2400$ & - & $8-(11.5)-13$ & - \\
\hline Poecilocalyx schumannil & - & + & - & - & - & - & 2,3 & $1000-(1566)-2100$ & - & $16-(20)-24$ & - \\
\hline P. stipulosa & - & + & + & - & - & + & 3,4 & $800-(1400)-2000$ & - & $10-(13)-15$ & - \\
\hline Stelechantha makakana & + & + & - & - & - & - & 2 & $1500-(1860)-3000$ & - & $21-(26)-30$ & - \\
\hline Prismatomeris sp. & - & + & - & - & - & - & 2,3 & $180-(795)-2000$ & - & $9-(11)-13$ & - \\
\hline P. beccariana (5423) & - & - & + & - & - & - & 2,3 & $400-(1222)-2550$ & - & $11-(15)-16$ & + \\
\hline P. beccariana (4336) & - & + & - & - & - & - & 2 & $600-(1265)-2200$ & - & $9-(11)-13$ & - \\
\hline P. brachypus & - & + & - & - & - & - & 1,2 & $?$ & - & $16-(20)-22$ & - \\
\hline P. tetrandra & - & + & + & - & - & - & 1,2 & $900-(1327)-2800$ & - & 15,16 & - \\
\hline Rennellia sp. & + & + & + & - & - & - & $1,2,3$ & $400-(1105)-2800$ & - & $13-(14)-16$ & - \\
\hline R. elliptica & - & - & + & - & - & - & $1,2,3$ & $600-(1792)-3700$ & - & $15-(17)-18$ & + \\
\hline $\begin{array}{l}\text { Triainolepis africana } 1040 \\
\text { (BR) }\end{array}$ & - & + & + & - & - & - & 2,3 & $1000-(1250)-2300$ & - & $14-(15)-17$ & + \\
\hline$T$. africana (Tw 19850) & - & + & + & - & - & - & 2,3 & $800-(1200)-1700$ & - & $15-(17)-20$ & + \\
\hline Leucolophus sp. & - & - & + & - & - & + & 4,5 & $900-(1954)-2500$ & + & $6-(7)-8$ & - \\
\hline Maschalocorymbus sp. & - & + & - & - & - & + & 4,5 & $900-(1262)-1700$ & + & $4-(5)-6$ & - \\
\hline M. corymbus & + & + & - & - & - & - & 5,6 & $1500-(2634)-3200$ & + & $10-(12)-13$ & - \\
\hline Pleiocarpidia sandahanica & + & + & - & - & - & + & 3,4 & $900-(1828)-2500$ & - & $7-(10)-11$ & - \\
\hline P. pilosa & - & + & - & - & - & - & 4,5 & $600-(1309)-1800$ & - & $6-(7)-9$ & - \\
\hline Praravinia sp. & - & + & - & - & - & + & 4,5 & $900-(1538)-2800$ & - & $4-(7)-13$ & - \\
\hline P. suberosa & - & + & + & - & - & + & 1,2 & $1200-(1417)-1900$ & - & $12-(16)-18$ & - \\
\hline Urophyllum of. macrophyllum & - & + & + & - & - & + & 2,3 & $1100-(1433)-2000$ & - & $10-(12)-15$ & - \\
\hline U. corymbosum & - & + & + & - & - & + & $1,2,(3)$ & $800-(1480)-2100$ & - & $12-(13)-15$ & - \\
\hline U. trifurcum & - & - & + & - & - & - & $1,(2)$ & $400-(710)-1200$ & - & $16-(20)-22$ & - \\
\hline U. zeylanicum & - & - & + & - & - & - & 3 & $1500-(1783)-2600$ & - & $13-(14)-16$ & - \\
\hline Lasianthus sp. (4026) & - & - & + & - & - & + & $1,2,3$ & $1500-(2511)-3600$ & - & $10-(11)-14$ & - \\
\hline L. sp. $(4034)$ & - & + & + & - & - & + & 2,3 & $700-(1466)-2400$ & - & $14-(14)-15$ & - \\
\hline L. sp. (4189) & - & - & + & - & - & + & 1 & $1100-(2111)-4400$ & - & $14-(17)-18$ & + \\
\hline L. acuminatus & - & + & + & - & - & - & 1,2 & $700-(1970)-3500$ & - & $13-(16)-19$ & - \\
\hline L. batangensis & - & + & + & - & - & - & 1 & $1700-(3280)-5600$ & - & $19-(20)-23$ & - \\
\hline L. batangensis (Tw 33582) & - & + & - & - & - & - & 2,3 & $300-(809)-2000$ & - & 12 & - \\
\hline L. cinereus & - & + & + & - & - & - & 1,2 & $?$ & - & $19-(22)-25$ & + \\
\hline L. mayumbensis & - & + & + & - & - & - & 1,2 & $370-(640)-1110$ & - & $8-(9)-10$ & - \\
\hline L. scabridus & - & - & + & - & - & - & 1 & $1200-(3220)-4000$ & - & $15-(16)-19$ & - \\
\hline Saldinia sp. (307) & - & + & - & - & - & - & 1 & $?$ & - & $15-(17)-19$ & - \\
\hline S. sp. (723) & - & + & - & - & - & - & 1 & $?$ & - & $20-(23)-26$ & - \\
\hline $\begin{array}{l}\text { Trichostachys microcarpa } \\
\text { (7678) }\end{array}$ & - & + & - & - & - & + & 1 & $1800-(2700)-5800$ & - & $16-(18)-20$ & + \\
\hline T. microcarpa (2883) & - & + & - & - & - & - & 1 & $?$ & - & $20-(23)-25$ & - \\
\hline
\end{tabular}


Trichostachys Hook.f. (1 species/2 specimens examined) -Figs. 36-39.

Growth rings are indistinct and formed by a difference in the fibre wall thickness and vessel frequency.-Vessels are diffuse. The mean vessel grouping index is 1.3. Vessel outline is round to oval. Vessels are $23(16-30) \mu \mathrm{m}$ wide. Vessel frequency is $160(150-200)$ per $\mathrm{mm}^{2}$. Vessel element length is $880(600-1,050) \mu \mathrm{m}$. About $80 \%$ of the vessel element perforations are scalariform (Fig. 38), with circa three bars; other perforations are simple. Intervessel pits and vessel-ray pits are minute, alternate, and vestured.-Fibres show bordered pits (3-4 $\mu \mathrm{m}$ in diameter) on radial and to a lesser extent on tangential walls. Septa are observed in at least several fibres. Mean fibre length is $1,200(680-1,550)$ $\mu \mathrm{m}$.-Axial parenchyma cells are sparsely diffuse, although they are difficult to distinguish from vessels in transverse sections (Fig. 36). Helical thickenings are occasionally found in axial parenchyma cells of T. microcarpa (R. Devred 7678; Fig. 39).--Rays are nearly always uniseriate, heterogeneous, and composed of upright/square ray cells (Fig. 37 ). Vessel-ray perforations are scalariform. Rays are generally more than $1 \mathrm{~mm}$ high, and about 20 rays occur per $\mathrm{mm}$. -Small and mainly navicular prismatic crystals are observed. Raphides are present in ray cells of $T$. microcarpa (7678).

\section{Discussion}

The Rubioideae studied in this paper show distinct differences in their wood anatomical characters. A summary of diagnostic features is given in Table 3.

As already recorded by Metcalfe and Chalk (1950) and Koek-Noorman (1969), the Coussareeae stand apart from the other Rubioideae by their scanty axial parenchyma. Our results agree with Koek-Noorman (1969: 386) who stated that Coussarea and Faramea "are as difficult to distinguish from each other as the woods of the Psychotrieae". The only difference between the two genera we observed is the higher amount of paratracheal parenchyma in Faramea. Coussareeae and Psychotrieae share septate libriform fibres and vessel element plates that show two or more simple perforations (Jansen et al. 1997). Psychotrieae, however, usually do not possess axial parenchyma and very high multiseriate rays. The presence of two ray sizes with high multiseriate rays that show sheath cells are a diagnostic feature of the Coussareeae. Moreover, vessel pits of Coussareeae are mostly polygonal and especially in Coussarea relatively large $(5-7 \mu \mathrm{m})$. Barros and Callado (1997) described scalariform perforation plates and prismatic crystals for the wood of Coussarea friburgensis, but these features were not found in the species studied by us.

As mentioned in the introduction, macromolecular data strongly support a relationship between Coussareeae and Coccocypseleae (e.g., Andersson and Rova 1999). Although the wood samples of Hindsia and Declieuxia studied are juvenile, the presence of septate fibres may support their relationship with the Coussareeae. Paratracheal parenchyma is not found in these genera, but several species of Coussarea also show very few or no axial parenchyma cells.
Other differences in wood anatomical features of Declieuxia and Hindsia are quantitative and thus should not be compared with the mature wood of Coussarea and Faramea.

The genus Craterispermum is characterised by the presence of continuous parenchyma bands and fibre-tracheids. Our wood data agree with earlier descriptions of Craterispermum (Normand and Paquis 1976, Lecomte 1922). Axial parenchyma bands are a relatively rare feature in Rubiaceae, but they are known in the Morindeae and Gaertnereae, which are placed near the Psychotrieae, as well as for Colletoecema (Jansen et al. 1996, 1997, Piesschaert et al. 2000a). These taxa with parenchyma bands also share fibre-tracheids. Based on macromolecular data, Bremer and Manen (2000) found that Craterispermum takes a well supported position in the Psychotrieae alliance.

Fibre-tracheids as well as the presence of axial parenchyma bands and solitary vessels in Colletoecema support an exclusion from the Psychotrieae (Piesschaert et al. 2000a). A position of Colletoecema in or near the Craterispermeae is a suggestion that deserves serious consideration. The two genera share habitual similarities (woody plants with congested axillary opposite inflorescences-a feature rare in Rubioideae) and both have drupes (in Craterispermum with a derived unilocular stone, in Colletoecema with a derived bilocular stone) (Igersheim 1992, Piesschaert et al. 2000a). There are also many floral similarities. Moreover, the two genera are strong aluminium accumulators and have similar wood characters.

Morindeae s.str. are characterised by parenchyma bands and fibre-tracheids, which support a close relationship between Morindeae and Gaertnereae as confirmed by molecular data (Bremer 1996), and these features distinguish them from Coussareeae and Psychotrieae. Morinda and Gynochtodes also share relatively large intervessel pits, which are sometimes up to $9 \mu \mathrm{m}$ in diameter.

The wood anatomy of Morinda is fairly heterogeneous with respect to axial parenchyma distribution, vessel grouping, and ray structure. Normand (1960) described Morinda geminata and M. lucida with numerous 4-6-seriate parenchyma bands, but remarks that this feature is not constant within the whole genus. He noticed that the Indian $M$. citrifolia can easily be distinguished from the African species $M$. lucida and $M$. geminata. Indeed, the axial parenchyma in M. citrifolia is diffuse-in-aggregates (Brown 1922, Janssonius 1926, Pearson and Brown 1932, Desch 1954). Vessels are exclusively solitary in several species, while others show radial multiples of more than four vessels. Most rays are heterogeneous, but in M. morindoides (UW 9264), and to a lesser extent $M$. geminata and $M$. citrifolia, homogeneous rays occur.

The wood anatomical variation in the Morindeae probably can be explained by its different growth forms. Morinda and Gynochtodes both contain woody climbers; this habit clearly influences the structure of the secondary xylem of taxa such as Gynochtodes, M. morindoides, and $M$. reticulata (see e.g. Carlquist 1985 for a general survey of the secondary xylem of vines). The vessel diameter in these species is wide, vessel elements are rather short, vessels are almost exclusively 
Table 3. Summary of diagnostic wood anatomical characters of the genera studied. $V G I=$ mean vessel grouping index; $\mathrm{VP}=$ vessel element perforation; $\mathrm{SI}=$ simple; $\mathrm{SC}=$ scalariform $; \mathrm{IR}=$ irregular $; \mathrm{DV}=$ mean tangential diameter of vessel lumina; $N=$ narrow $(\leq 50 \mu \mathrm{m}) ; \mathrm{M}=$ medium $(50-100 \mu \mathrm{m}) ; \mathrm{W}=$ wide $(100-200 \mu \mathrm{m}) ; \mathrm{WW}=$ very wide $(\geq 200 \mu \mathrm{m}) ; \mathrm{SF}=$ septate fibres; $A P=$ axial parenchyma; $D=$ diffuse; $D A=$ diffuse-in-aggregates; $N B=$ narrow bands; $W B=$ wide bands ; $P=$ paratracheal ; $H T=$ helical thickenings in axial parenchyma cells ; $R W=$ ray width given in cell numbers ; $\mathrm{SC}=$ sheath cell ; $+=$ present ; $-=$ absent.

\begin{tabular}{|c|c|c|c|c|c|c|c|c|}
\hline $\begin{array}{l}\text { Tribe } \\
\text { Genus }\end{array}$ & VGI & VP & DV & SF & $\mathrm{AP}$ & HT & RW & SC \\
\hline \multicolumn{9}{|l|}{ Coccocypseleae } \\
\hline Declieuxia & 1.23 & SI & $\mathrm{N}$ & + & - & - & $1-3$ & - \\
\hline Hindsia & 1.76 & S! & $N$ & + & - & - & $1-2$ & - \\
\hline \multicolumn{9}{|l|}{ Coussareeae } \\
\hline Coussarea & 1.65 & SI & $N, M, M$ & + & $P,-$ & - & $1,(2-3),>3$ & + \\
\hline Faramea & 1.62 & SI & $\mathrm{N}, \mathrm{M}$ & + & $\mathrm{P}$ & - & 1, $(2-3),>3$ & + \\
\hline \multicolumn{9}{|l|}{ Craterispermeae } \\
\hline Craterispermum & 1.20 & SI & $\mathrm{N}, \mathrm{M}$ & - & WB & - & $1-2-3$ & - \\
\hline \multicolumn{9}{|l|}{ Mitchella group } \\
\hline Damnacanthus & 1 & SI, IR & $N$ & + & - & - & $1-(2)$ & - \\
\hline \multicolumn{9}{|l|}{ Morindeae } \\
\hline Gynochtodes & 1.0 & SI & (W)-WW & - & WB & - & $1-(2)$ & - \\
\hline Morinda & $1-2$ & SI & $(\mathrm{N}), \mathrm{M}, \mathrm{W},(\mathrm{M})$ & - & D, DA, NB, WB & - & $1-(2), 2-3-(5)$ & - \\
\hline \multicolumn{9}{|l|}{ Pauridiantheae } \\
\hline Commitheca & 1.42 & SI & $\mathrm{N}$ & - & $\mathrm{D}$ & + & $2-3$ & - \\
\hline Pauridiantha & 1.8 & SI & $\mathrm{N},(\mathrm{M})$ & - & $D, D A$ & + & $2-3-(5)$ & - \\
\hline Poecilocalyx & 1.15 & SI & $\mathrm{N}$ & - & $D, D A$ & + & $2-3-4$ & - \\
\hline Stelechantha & 1.50 & SI & $N$ & - & $\mathrm{D}, \mathrm{P}$ & - & 2 & - \\
\hline \multicolumn{9}{|l|}{ Prismatomerideae } \\
\hline Prismatomeris & 1.0 & SI & $\mathrm{N}, \mathrm{M}$ & - & $\mathrm{D}$ & - & $2-(3)$ & - \\
\hline Rennellia & 1.0 & SI & $(\mathrm{N}), \mathrm{M}$ & - & $D, D A$ & - & $2-3$ & - \\
\hline \multicolumn{9}{|l|}{ Triainolepideae } \\
\hline Triainolepis & 2.70 & $\mathrm{SI}$ & $\mathrm{N},(\mathrm{M})$ & - & $D, D A$ & - & $2-3$ & - \\
\hline \multicolumn{9}{|l|}{ Urophylleae } \\
\hline Leucolophus & 1.0 & SI & $N, M$ & - & DA & + & $4-5$ & + \\
\hline Maschalocorymbus & 1.25 & SI & $M,(W)$ & - & $\mathrm{D}, \mathrm{P}$ & + & $4-5-6$ & + \\
\hline Pleiocarpidia & 1.45 & $\mathrm{SI}$ & $M, W$ & - & $\mathrm{D}, \mathrm{P}$ & + & $3-4-5$ & - \\
\hline Praravinia & 1.20 & SI & $\mathrm{N}, \mathrm{M}$ & - & $D, D A$ & + & $1-2,4-5$ & - \\
\hline Urophyllum & 1.63 & SI & $N,(W)$ & - & $D, D A$ & + & $1-2-3$ & - \\
\hline \multicolumn{9}{|l|}{ Lasianthus group } \\
\hline Lasianthus & 1.23 & SI & $\mathrm{N},(\mathrm{M})$ & - & $D, D A$ & + & $1-2-(3)$ & - \\
\hline Saldinia & 1.30 & $\mathrm{SI},(\mathrm{SC})$ & $N$ & - & $\mathrm{D}$ & - & 1 & - \\
\hline Trichostachys & 1.30 & $\mathrm{SC},(\mathrm{SI})$ & $N$ & - & (D) & + & 1 & - \\
\hline
\end{tabular}

solitary, axial parenchyma bands are wide, and the rays are homogeneous and mainly uniseriate.

The presence of styloids in Morinda morindoides (Uw 9264) is remarkable, since this crystal type is unusual in wood of Rubiaceae; they are found for instance in Cosmocalyx, Ixora, Captaincookia, and Versteegia (Richter and Schmitt 1987, Jansen et al. 1999). Among Rubioideae, relatively thin styloids are found in the leaves of some Psychotrieae (Solereder 1893, SJ: pers. obser.).
The secondary xylem of the Prismatomerideae (Prismatomeris and Rennellia) shows exclusively solitary vessels, fibre-tracheids, heterogeneous bi- or triseriate rays, and diffuse to diffuse-in-aggregates parenchyma cells. The absence of axial parenchyma bands and the occurrence of solitary vessels indicates that Prismatomeris and Rennellia can be distinguished from the Morindeae s.str., but further data from the remaining genera (Appunia, Caelospermum, Pogonolobus, Gentingia, Motleya) are desirable. 
Although the wood sample of Damnacanthus indicus available is juvenile, two features appear to be of taxonomic significance: the absence of axial parenchyma and the presence of septate libriform fibres. Septate fibres with the occasional presence of vesturing on newly deposited thickenings have already been illustrated in detail and much more accurately by Ohtani (1987). This feature appears to be unique in Rubiaceae and as far as we know is not reported in other families. Ohtani (1984) also reported the unusual openings of the perforation plates in this species. In the molecular analysis of Andersson and Rova (1999) the Mitchella group was strongly nested in the Morindeae. Wood anatomically, however, Damnacanthus differs from the Morindeae and Prismatomerideae.

While Lasianthus has traditionally been placed in the Psychotrieae (Hooker 1873, Schumann 1897, Verdcourt 1958, Robbrecht 1993) or the Morindeae (Petit 1964, Robbrecht 1988), $r b c \mathrm{~L}$ and $r p s 16$ intron sequence data strongly support a basal position of this genus within the Rubioideae, close to the neotropical herbaceous genus Perama (Bremer 1996, Andersson and Rova 1999). Wood anatomical features, especially the presence of fibre-tracheids and axial parenchyma which is diffuse to diffuse-in-aggregates, demonstrate that a position of Lasianthus within the Psychotrieae is no longer justified.

Helical thickenings in the axial parenchyma are seldom recorded in the secondary xylem of dicotyledons. Sporadic occurrence has been reported in Lasianthus by Janssonius (1926) and Ohtani (1986). Other examples are for instance Trigonia servicea (Trigoniaceae, Heimsch 1941), few Dipterocarpaceae, Ancistrocladaceae (Gottwald and Parameswaran 1966,1968), Chrysobalanaceae (ter Welle 1975), and Araliaceae (Oskolski and Lowry 2000). Although the feature is very easily overlooked, we suggest that it characterises the basal most taxa of the Rubioideae, including Pauridiantheae, Urophylleae, and the group of Lasianthus. Within one sample the thickenings are of sporadic occurrence and fewer than $1 \%$ of axial parenchyma cells have these thickenings. Our observations confirm Ohtani (1986) in that they are more frequent in parenchyma cells which are in contact with or close to the (narrow) vessels. As illustrated by Ohtani (1986) in Lasianthus japonicus, it would be interesting to examine by detailed SEM observations whether or not vestures are associated with the thickenings that are found in axial parenchyma cells of other basal Rubioideae. Except for Rubiaceae, the unusual occurrence of vestures in axial parenchyma cells may also be present in Trigoniaceae and Dipterocarpaceae, which both show vestured vessel pits (Jansen et al. 2001).

Other genera that have been associated with the Psychotrieae or Morindeae are Trichostachys and Saldinia (Petit 1963, Robbrecht 1993). The rps16 intron analysis in Piesschaert et al. (2000a) demonstrated that these genera belong to the Lasianthus clade. Support for this position is found in the presence of distinctly bordered pits and the rare occurrence of helical thickenings in the axial parenchyma cells of Trichostachys. On the other hand, the presence of at least a few septate fibres in Saldinia and Trichostachys is not observed in species of Lasianthus. The scalariform perforation plates and uniseriate rays probably can be explained by the juvenile wood samples. The specimens of Trichostachys microcarpa studied have a monocaul dwarf habit: representatives are low (ca. $1 \mathrm{~m}$ ), unbranched woody plants with most leaves aggregated towards the tip (Robbrecht 1988).

The tribes Pauridiantheae and Urophylleae, which were previously placed in the subfamily Cinchonoideae sensu Robbrecht $(1988,1993)$, show relatively similar wood features. The genera of these tribes can not be distinguished from each other by wood anatomy only. The wood structure of this group can be interpreted as rather primitive with the presence of fibre-tracheids, diffuse to diffuse-in-aggregate axial parenchyma, and vessel groupings are mostly solitary.

Our major conclusion is that wood anatomy generally corroborates the delimitation and separation of several taxa from the former Coussareeae/Morindeae/Prismatomerideae/Psychotrieae aggregate. In fact, wood anatomy appears to be most applicable to systematics of the Rubiaceae in statements of negation of close relationship rather than positive assertions of close affinity. Moreover, a comparison of the wood structure with independently suggested phylogenies of the Rubioideae suggests that homoplasy (several origins and/or losses) most likely explains the wood anatomical variation. A general treatment of the wood anatomical tendencies in the Rubiaceae will be discussed in a forthcoming paper.

Anja Vandeperre is acknowledged for her excellent microtechnical work and the reproduction of the photographs. We thank Dr. P. Baas (Leiden), Dr. J. Koek-Noorman (Utrecht), and Dr.H. Beeckman (Tervuren) for the generous supply of wood samples. This research is supported by a grant from the Research Council of the K.U. Leuven (OT/97/ 23) and by a grant from the Fund for Scientific Research -Flanders (project number G.0104.01). Salvator Ntore holds a scholarship of the Government of Burundi.

\section{References}

Andersson, L. and Rova, J.H.E. 1999. The rps16 intron and the phylogeny of the Rubioideae (Rubiaceae). Plant Syst. Evol. 214: 161-186.

Andreasen, K. and Bremer, B. 2000. Combined phylogenetic analysis in the Rubiaceae-lxoroideae: morphology, nuclear and chloroplast DNA data. Amer. J. Bot. 87: 1731-1748.

Barros, C.F. and Callado, C.H. 1997. Timbers of the Atlantic rain forest. Wood anatomy of species from remnant forests in Rio de Janeiro State-Brazil. Volume 1. Jardim Botanico do Rio de Janeiro, Brazil.

Bremekamp, C.E.B. 1966. Remarks on the position, the delimitation and the subdivision of the Rubiaceae. Acta Bot. Neerl. 15: 1-33.

Bremer, B. 1996. Phylogenetic studies within Rubiaceae and relationships to other families based on molecular data. In E. Robbrecht, C. Puff and E. Smets, eds., Second International Rubiaceae Conference, Proceed- 
ings. Opera Bot. Belg. 7: 33-50.

Bremer, B., Andreasen, K. and Olsson, D. 1995. Subfamilial and tribal relationships in the Rubiaceae based on $r b c L$ sequence data. Ann. Missouri Bot. Gard. 82: 383397.

Bremer, B. and Manen, J.-F. 2000. Phylogeny and classification of the subfamily Rubioideae (Rubiaceae). Plant Syst. Evol. 225: 43-72.

Bremer, B. and Thulin, M. 1998 . Collapse of Isertieae, reestablishment of Mussaendeae, and a new genus of Sabiceeae (Rubiaceae); phylogenetic relationships based on $r b c L$ data. Plant Syst. Evol. 211: 71-92.

Brown, F.B.H. 1922. The secondary xylem of Hawailan trees. Occ. Pap. B. P. Bishop Mus. 8: 217-371.

Carlquist, S. 1985 . Observations on functional wood histology of vines and lianas: vessel dimorphism, tracheids, vasicentric tracheids, narrow vessels, and parenchyma. Aliso 1t: 139-157.

Carlquist, S. 1988. Comparative Wood Anatomy. Systematic, Ecological, and Evolutionary Aspects of Dicotyledon Wood. Springer-Verlag, Berlin.

Darwin, S.P. 1979. A synopsis of the indigenous genera of Pacific Rubiaceae. Allertonia 2: 1-44.

Desch, H.E. 1954. Manual of Malayan timbers. Vol. II. Malayan For. Rec. 15: 329-762.

Gottwald, H. and Parameswaran, N. 1966. Das sekundäre Xylem der Familie Dipterocarpaceae, anatomische Untersuchungen zur Taxonomie und Phylogenie. Bot. Jahrb. 85: 410-508.

Gottwald, H. and Parameswaran, N. 1968. Das sekundäre Xylem und die systematische Stellung der Ancistrocladaceae und Dioncophyllaceae. Bot. Jahrb. 88: 4969.

Heimsch, Ch. Jr. 1941. Comparative anatomy of the secondary xylem in the Gruinales and Terebinthales of Wettstein with reference to taxonomic grouping. Lilloa 8: 83-198.

Hooker, J.D. 1873. Ordo LXXXIV. Rubiaceae. In G. Bentham and J.D. Hooker, eds., Genera plantarum ad exemplaria imprimis in herbariis kewensibus servata defirmata 2, London, pp. 7-151.

IAWA Committee. 1989. IAWA list of microscopic features for hardwood identification. IAWA Bull. n.s. 10: 219332.

Igersheim, A. 1992. The ovary, fruit and seed development of Craterispermum (Rubiaceae). Belg. J. Bot. 125: 101113.

Igersheim, A. and Robbrecht, E. 1993. The character states and relationships of the Prismatomerideae (Rubiaceae-Rubioideae). Comparisons with Morinda and comments on the circumscription of the Morindeae s.str. In E. Robbrecht, ed., Advances in Rubiaceae Macrosystematics. Opera Bot. Belg. 6: 61-79.

Jansen, S., Baas, P. and Smets, E. 2001. Vestured pits: their occurrence and systematic importance in eudicots. Taxon 50: 135-167.

Jansen, S., De Block, P., Beeckman, H., and Smets, E. 1999. Systematic wood anatomy of the Pavetteae (Rubiaceae, Ixoroideae). Syst. Geogr. PI. 68: 113-133.

Jansen, S., Dessein, S., Piesschaert, F., Robbrecht, E. and Smets, E. 2000a. Aluminium accumulation in leaves of Rubiaceae: systematic and phylogenetic implications. Ann. Bot. 85: 91-101.

Jansen, S., Kitin, P., De Pauw, H., Idris, M., Beeckman, H. and Smets, E. 1998. Preparation of wood specimens for transmitted light microscopy and scanning electron microscopy. Belg. J. Bot. 131: 41-49.

Jansen, S., Robbrecht, E., Beeckman, H. and Smets, E. 1996. Gaertnera and Pagamea: genera within the Psychotrieae or constituting the tribe Gaertnereae? A wood anatomical and palynological approach. Bot. Acta 109: 466-476.

Jansen, S., Robbrecht, E., Beeckman, H. and Smets, E. 1997. Wood anatomy of the predominantly African representatives of the tribe Psychotrieae (RubiaceaeRubioideae). I.A.W.A. Bull., N.S. 18: 169-196.

Jansen, S., Robbrecht, E., Beeckman, H. and Smets, E. 2000b. Aluminium accumulation in Rubiaceae: an additional character for the delimitation of the subfamily Rubioideae? I.A.W.A. Bull., N.S. 21: 197-212.

Janssonius, H.H. 1926. In J.W. Moll and H.H. Janssonius, eds., Mikrografie des Holzes der auf Java vorkommenden Baumarten. IV. Brill E.J., Leiden.

Koek-Noorman, J. 1969. A contribution to the wood anatomy of South American (chiefly Surinam) Rubiaceae. II. Acta Bot. Neerl. 18: 377-395.

Lecomte, H. 1922. Madagascar. Les bois de la forêt d'Analamazaotra. A. Challamel, Paris.

Manen, J.F. and Natali, A. 1996. The chloroplast atpB-rbcL spacer in Rubiaceae. In E. Robbrecht, C. Puff and E. Smets, eds., Second International Rubiaceae Conference, Proceedings. Opera Bot. Belg. 7: 51-57.

Metcalfe, C.R. and Chalk, L. 1950. Anatomy of the Dicotyledons. Clarendon Press, Oxford.

Normand, D. 1960 . Atlas des bois de la Côte d'lvoire. Volume III. Centre Tech. For. Trop., Nogent-sur-Marne.

Normand, D. and Paquis, J. 1976. Manuel d'Identification des bois commerciaux. 2. Afrique guinéo-congolaise. Centre Tech. For. Trop., Nogent-sur-Marne.

Ohtani, J. 1984. SEM observations on perforation plates in some Rubiaceae. In Pacific Regional Wood Anatomy Conference, Tsukuba, pp. 61-63.

Ohtani, J. 1986. Vestures in axial parenchyma cells. I.A.W.A. Bull., N.S. 7: 39-45.

Ohtani, J. 1987. Vestures in septate wood fibres. I.A.W.A. Bull., N.S. 8: 59-67.

Oskolski, A.A. and Lowry, P.P. Il. 2000. Wood anatomy of Mackinlaya and Apiopetalum (Araliaceae) and its systematic implications. Ann. Missouri Bot. Gard. 87: 171-182.

Pearson, R.S. and Brown, H.P. 1932. Commercial timbers of India. Volume 2. Their distribution, supplies, anatomical structure, physical and mechanical properties and uses. Central Publ. Branch, Govt. of India, Calcutta.

Petit, E. 1963. Rubiaceae africanae X. Colletoecema genre nouveau de Rubiaceae. Bull. Rijksplantentuin Bruss. 34: 375-380.

Petit, E. 1964. Les espèces africaines du genre Psychotria L. (Rubiaceae). I. Bull. Rijksplantentuin Bruss. 34: 1228.

Piesschaert, F., Andersson, L., Jansen, S., Dessein, S., 
Robbrecht, E. and Smets, E. 2000a. Searching for the taxonomic position of the African genus Colletoecema (Rubiaceae): morphology and anatomy compared to an rps16-intron analysis of the Rubioideae. Canad. J. Bot. 78: $288-304$.

Piesschaert, F., Huysmans, S., Jaimes, l., Robbrecht, E. and Smets, E. 2000b. Morphological evidence for an extended tribe Coccocypseleae (RubiaceaeRubioideae). Plant Biol. 2: 536-543.

Richter, H.G. and Schmitt, U. 1987. Unusual crystal formations in the secondary xylem of Cosmocalyx spectabilis Standl. (Rubiaceae). I.A.W.A. Bull., N.S. 8: 323-329.

Robbrecht, E. 1988. Tropical woody Rubiaceae. Characteristic features and progressions. Contributions to a new subfamilial classification. Opera Bot. Belg. 1: 1271.

Robbrecht, E. 1993. Supplement to the 1988 outline of the classification of the Rubiaceae. Index to genera. In E. Robbrecht, ed., Advances in Rubiaceae macrosystematics. Opera Bot. Belg. 6: 173-196.

Robbrecht, E., Puff, C. and Igersheim, A. 1991. The genera Mitchella and Damnacanthus, evidence for their close alliance; comments on the campylotropy in the Rubiaceae and the circumscription of the Morindeae. Blumea 35: 307-345.

Schumann, K. 1897. Rubiaceae. In A. Engler and K. Prantl, eds., Die Natürlichen Pflanzenfamilien. Nachtr. I zum II-IV Teil, Engelmann, Leipzig, pp. 309-316.

Solereder, H. 1893. Ein Beitrag zur anatomischen Charakteristik und zur Systematik der Rubiaceen. Bull. Herb. Boissier 1: 309-326

Ter Welle, B.J.H. 1975. Spiral thickenings in the axial parenchyma of Chrysobalanaceae. Acta Bot. Neerl. 24: $397-405$.

Verdcourt, B. 1958. Remarks on the classification of the Rubiaceae. Bull. Rijksplantentuin Bruss. 28: 209-281.

Young, M.C.M., Braga, M.R., Dietrich, S.M.C., Bolzani, V.S., Trevisan L.M.V. and Gottlieb, O.R. 1996. Chemosystematic markers of Rubiaceae. In E. Robbrecht, C. Puff and E. Smets, eds., Second International Rubiaceae Conference, Proceedings. Opera Bot. Belg. 7: 205-212.

(Received January 26, 2001; accepted June 6, 2001) 